\title{
Influence of Harvest Timing, Fungicides, and Beet necrotic yellow vein virus on Sugar Beet Storage
}

Carl A. Strausbaugh, United States Department of Agriculture-Agricultural Research Service (USDA-ARS) NWISRL, Kimberly, ID 83341; Oliver Neher, Amalgamated Sugar Company, Boise, ID 83709; Eugene Rearick, Amalgamated Research LLC, Twin Falls, ID 83301; and Imad A. Eujayl, USDA-ARS NWISRL, Kimberly

\begin{abstract}
Strausbaugh, C. A., Neher, O., Rearick, E., and Eujayl, I. A. 2015. Influence of harvest timing, fungicides, and Beet necrotic yellow vein virus on sugar beet storage. Plant Dis. 99:1296-1309.

Root rots in sugar beet storage can lead to multimillion dollar losses because of reduced sucrose recovery. Thus, studies were conducted to establish additional fungicide treatments for sugar beet storage and a greater understanding of the fungi involved in the sugar beet storage rot complex in Idaho. A water control treatment and three fungicides (Mertect [product at $0.065 \mathrm{ml} / \mathrm{kg}$ of roots; $42.3 \%$ thiabendazole $\{\mathrm{vol} / \mathrm{vol}\}$ ], Propulse [product at $0.049 \mathrm{ml} / \mathrm{kg}$ of roots; $17.4 \%$ fluopyram and $17.4 \%$ prothioconazole $\{\mathrm{vol} / \mathrm{vol}\}$ ], and Stadium [product at $0.13 \mathrm{ml} / \mathrm{kg}$ of roots; $12.51 \%$ azoxystrobin, $12.51 \%$ fludioxonil, and $9.76 \%$ difenoconozole $\{\mathrm{vol} / \mathrm{vol}\}])$ were investigated for the ability to control fungal rots of sugar beet roots held up to 148 days in storage during the 2012 and 2013 storage seasons. At the end of September into October, roots were harvested weekly for 5 weeks from each of two sugar beet fields in Idaho, treated with the appropriate fungicide, and placed on top of a commercial indoor sugar beet storage pile until early February. Differences $(P<0.0001$ to 0.0150$)$

among fungicide treatments were evident. Propulse- and Stadiumtreated roots had 84 to $100 \%$ less fungal growth versus the control roots, whereas fungal growth on Mertect-treated roots was not different from the control roots in 7 of 12 comparisons for roots harvested each of the first 3 weeks in both years of this study. The Propulse- and Stadiumtreated roots also reduced $(P<0.0001$ to 0.0146 ; based on weeks 1 , 3 , and 4 in 2012 and weeks 1, 3, 4, and 5 in 2013) sucrose loss by 14 to $46 \%$ versus the control roots, whereas roots treated with Mertect did not change sucrose loss compared with the control roots in 7 of 10 evaluations. The predominant fungi isolated from symptomatic roots were an Athelia-like sp., Botrytis cinerea, Penicillium spp., and Phoma betae. If Propulse and Stadium are labeled for use on sugar beet in storage, these fungicides should be considered for root rot control in commercial sugar beet storage and on roots held for vernalization for seed production of this biennial plant species.
\end{abstract}

Sugar beet (Beta vulgaris L.) roots are typically stored for long periods of time in outdoor piles or storage buildings in some production areas, because factories do not always have the capacity to process the whole crop at harvest (9). In Idaho, about two-thirds of the crop typically has to be stored for some period $(26,37,51)$. Roots are stored for an average of 60 to 70 days but some may be stored for up to 160 days in Idaho (26). During the 2012 and 2013 sugar production period in Idaho, factory processing of sugar beet roots was initiated in mid-September and did not finish until the end of March or early April (26). Storing sugar beet roots for lengthy periods of time under ambient conditions can be a challenge because of adverse weather conditions and microbial growth on the roots $(9,29)$. In Idaho, the average annual cost of beet storage losses from 2010 to 2012 was $\$ 6.40 /$ ton of roots harvested, and an estimated 4.8 to 5.8

Corresponding author: C. A. Strausbaugh;

E-mail: carl.strausbaugh@ars.usda.gov

Mention of trade names or commercial products in this article is solely for the purpose of providing scientific information and does not imply recommendation or endorsement by the U.S. Department of Agriculture.

GenBank accessions: KM249066 to KM249138.

*The $\boldsymbol{e}$-Xtra logo stands for "electronic extra" and indicates that one supplementary table is published online.

Accepted for publication 28 February 2015.

http://dx.doi.org/10.1094/PDIS-10-14-0998-RE

(C) 2015 The American Phytopathological Society million tons of roots were harvested annually during this period in Idaho (26). Thus, millions of dollars can be lost to storage problems annually in Idaho and across the United States $(8,11,26,56)$.

In areas with cold winter temperatures such as North Dakota, roots in both outdoor and indoor piles usually are frozen solid by midDecember when ambient temperatures average $\leq-10^{\circ} \mathrm{C}$, which stabilizes the roots for long-term storage $(6,8,9)$. In areas such as Idaho, Wyoming, and Michigan, with roots stored under ambient conditions, only roots near the pile surface freeze because temperatures are either not cold enough or fluctuate too much to maintain the roots in the whole pile in a frozen state $(8,9)$. Roots stored under such ambient conditions are subject to freeze-thaw cycles, wet weather, warm nights which does not allow for cooling of the piles of roots, and control of microbial growth $(8,9,51,52,62)$. For example, when $20 \%$ of the sugar beet root surface was covered by fungal growth, the respiration rate of the stored sugar beet roots doubled within 1 month (32). In addition, roots from plants subjected to diseases in the field such as Aphanomyces root rot (Aphanomyces cochlioides Drechsler), Cercospora leaf spot (Cercospora beticola Sacc.), curly top (Beet curly top virus), Fusarium yellows (Fusarium oxysporum f. sp. betae W. C. Snyder \& H. N. Hansen), Rhizoctonia root rot (Rhizoctonia solani Kühn), and rhizomania (Beet necrotic yellow vein virus [BNYVV]) store more poorly than roots produced by healthy plants (15-17,27,44,50-52).

One sugar beet disease of primary concern in both the field and storage is rhizomania $(42,49,51)$. Because rhizomania is widespread in many production areas, host resistance to BNYVV is required for a sugar beet cultivar to be approved for production by seed committees in the United States $(33,42)$. In addition, BNYVV has been shown to affect sugar beet storage by causing a loss of sucrose $(17,49,51)$. The virus is thought to increase sucrose loss by increasing root respiration (17) or by facilitating microbial growth on the roots that subsequently 
leads to sucrose reduction (49,51). More surface root rot was noted on roots from BNYVV-infested fields versus roots from fields with only trace incidences of BNYVV, with the majority of the fungal growth associated with an Athelia-like basidiomycete, although Penicillium and Botrytis spp. were also present frequently $(49,51,55)$.

Identifying sources of sugar beet resistance and use of cultivars with resistance to storage rots can alleviate losses to rot in storage $(10,13,47-49)$. However, given the significant losses currently suffered in storage in Idaho, host resistance and cultivar selection alone are not enough to deal with storage problems $(9,12,26,46)$. Currently, physical control practices such as tarping, ventilation, and stripping the outer meter of sugar beet roots from the pile surface are utilized to reduce storage losses $(6,37,38,57)$. Although these physical methods reduce sucrose losses, additional control measures for storage such as chemical treatments have been investigated $(1,12,23,31,32,61)$. In an effort to reduce fungal growth in piles of sugar beet roots, the fungicide thiabenzadole (marketed as $\mathrm{HDH}$ TBZ [Environmental Protection Agency Registration Number (EPA Reg. No.) 43410-33-83103]; HDH Agri Products, LLC, Tavares, FL) has been labeled for use on sugar beet roots in the United States $(1,12)$. Thiabenzadole was originally marketed as Mertect 340F (Syngenta Crop Protection, LLC, Greensboro, NC) but the current label for that product (EPA Reg. No. 100-889) does not include sugar beet. The use of thiabenzadole to control fungal rots in sugar beet storage piles has not been adopted in Idaho, because fungal growth was still evident on the roots, sucrose loss measured in the factory did not change, and pressing of the root tissue coming out of the diffuser was negatively affected (O. Neher, personnel communication). Therefore, the efficacy of alternative fungicides should be investigated for use in Idaho sugar beet storage. To this end, the efficacy of two recently developed fungicides, Propulse (active ingredients fluopyram and prothioconazole; Bayer CropScience, Research Triangle Park, NC) and Stadium (active ingredients azoxystrobin, fludioxonil, and difenoconozole; Syngenta Crop Protection, LLC), with the potential for broad-spectrum fungal control, were evaluated in this study along with other variables that can affect sugar beet rot in storage (i.e., root harvest timing and BNYVV) $(17,49,51)$. Because Idaho commercial indoor sugar beet storage buildings are approximately $75 \%$ full by mid-October each year (C. A. Strausbaugh, personal observation), roots were harvested weekly over the 5-week period leading up to mid-October in each of 2012 and 2013 from each of two fields near Kimberly, ID with trace incidence and one with high incidence of BNYVV to establish whether the fungicides Propulse and Stadium can control rot root and sucrose loss in sugar beet roots compromised by this virus.

\section{Materials and Methods}

Storage study, 2012. The commercial sugar beet 'B-5' (Betaseed, Inc., Kimberly, ID), which is partially resistant to BNYVV and intermediate for storability (ranked 12 of 31 cultivars in 2011 and 21 of 26 cultivars in 2012 for recoverable sucrose in studies in Idaho) $(47,48)$, was planted and managed using standard cultural practices for Idaho as mentioned in the 2012 Sugarbeet Grower's Guide (Amalgamated Sugar Company, LLC, Boise, ID). B-5 was planted in a field with a high incidence of rhizomania ( 90 to $100 \%$ of the plants in a neighboring susceptible cultivar, 'B-54' [Betaseed, Inc.], had foliar symptoms) and a field with a low incidence $(<1 \%$ of the neighboring susceptible B-54 plants had foliar symptoms) incidence of rhizomania to provide a source of roots for this study. On 19 September 2012, 26 sugar beet root samples ( $n=8$ roots/sample) were randomly hand dug and topped from each field, and placed in a polyethylene mesh onion bag (Idaho Package Company, Idaho Falls, ID). In all, 2 of the eight-root samples from each field were analyzed at the Amalgamated Sugar Company tare laboratory (Paul, ID) to establish baseline harvest yield data for percent sucrose, conductivity, and nitrates; and the other 24 eight-beet samples from each field were subjected to one of four treatments (nontreated control treatment or treatment with one of three fungicides, as described below) and placed in an indoor commercial storage building in Paul, ID (temperature set point of $1.1^{\circ} \mathrm{C}$, relative humidity was not controlled but remained $>90 \%$, with the building cooled using ambient air).
The experimental design was a randomized complete block with six replications. The two field treatments (high versus low incidences of rhizomania) and four fungicide treatments (water versus one of three fungicides) formed a two-by-four factorial treatment design for a total of 48 eight-beet samples collected each week of harvest. Prior to placing the roots in storage, the fungicides applied included Mertect 340F (42.3\% thiabendazole [vol/vol]; Syngenta Crop Protection, LLC) with product at $0.065 \mathrm{ml} / \mathrm{kg}$ of roots, Propulse (17.4\% fluopyram and $17.4 \%$ prothioconazole [vol/vol]; Bayer CropScience) with product at $0.049 \mathrm{ml} / \mathrm{kg}$ of roots, and Stadium (12.51\% azoxystrobin, $12.51 \%$ fludioxonil, and $9.76 \%$ difenoconozole [vol/vol]; Syngenta Crop Protection, LLC) with product at $0.13 \mathrm{ml} / \mathrm{kg}$ of roots. The fungicides were diluted in well water and applied in a volume of $8.34 \mathrm{ml} / \mathrm{kg}$ of roots using a $\mathrm{CO}_{2}$-pressurized backpack sprayer equipped with a wand and a band nozzle (Model 8004EVS; TeeJet Technologies, Wheaton, IL) at a pressure of $2.8 \mathrm{~kg} / \mathrm{cm}^{2}$.

For the first year of this study, fungal growth on the surface of each root was evaluated visually on 15 January 2013 and again on 7 February 2013 to establish the percentage of root area covered by fungal growth. On 8 February, five samples from each aerial mycelium type (based on mycelial morphology and color) were collected from roots across all treatment combinations to identify the fungi growing on the surface of the roots. The 48 samples remained in storage until $13 \mathrm{Feb}-$ ruary (148 days). Just prior to processing the roots on 13 February for brei samples (shredded root tissue from brei saw), the roots were weighed, a surface root rot evaluation was conducted (percentage of discolored root surface area), and 5 root samples with rot (including all lesion types) for each of the four treatments (water control and three fungicides) were collected (20 root samples regardless of the field for a total of 100 samples across the five sampling periods after harvest within each year) for fungal isolation from internal root tissue under each lesion. The storage temperature was recorded at 1-h intervals using Hobo sensors (Model H08-001-02; Onset Computer Corp., Bourne, MA) located in the root storage pile. The harvest and treatments of roots were repeated four times at weekly intervals, with the second, third, fourth, and fifth harvest times initiated on 26 September and 3, 10, and 17 October, respectively. The final visual evaluations of roots sampled at each harvest interval were conducted at the same time in January and February, as mentioned above.

Storage study, 2013. The series of five sample timings after harvest conducted in 2012 were repeated using roots harvested from adjoining areas of the same fields in 2013. The incidence of symptoms in susceptible B-54 (planted next to B-5) was the same as in 2012. The 2013 B-5 roots were harvested on 18 and 25 September and 4, 9, and 16 October. Fungal growth on the root surface was evaluated visually on 17 January 2014 and again on 5 February 2014, as described for the 2012-13 trial. On 6 February, five samples from each aerial mycelium type observed on the root surfaces were collected at random from roots sampled at each weekly harvest to identify the fungi associated with the surface of roots. The samples remained in storage until 10 February (145 days for week 1 samples versus 117 days for week 5 samples).

Fungal isolations. To determine the identity of fungi producing aerial mycelium and present in rotted sugar beet root tissue under the surface lesions, isolations were conducted. The aerial mycelium was directly sampled onto potato dextrose agar (PDA; Becton Dickinson \& Co., Sparks, MD) amended with streptomycin ( $200 \mathrm{mg} / \mathrm{liter})$. The fungi in root tissue were isolated by surface-sterilizing tissue sampled from the leading edge of discolored root lesions, using $0.5 \% \mathrm{NaOCl}$ ( $\mathrm{vol} / \mathrm{vol}$ ) for $1 \mathrm{~min}$, followed by rinsing the root sections in sterilized reverse-osmosis water for $1 \mathrm{~min}$, removing the surface tissue, and transferring the sample onto PDA amended with streptomycin ( $200 \mathrm{mg} / \mathrm{liter})$. The plates were incubated on the laboratory bench at $22^{\circ} \mathrm{C}$. The fungal cultures were hyphal tipped or single spored to establish pure cultures. Morphocultural characteristics of the cultures were used to establish an initial identification to genus or species, which was later confirmed through DNA sequencing, as described below.

Molecular characterization of fungi. To confirm the fungal identifications established based on morphocultural characteristics, cultures of each mycelial type (up to six for the most frequent types) were arbitrarily selected and investigated by sequencing the following 
DNA regions: $\beta$-tubulin (TUB), glyceraldehyde-3-phosphate dehydrogenase (G3PDH), heat-shock protein 60 (HSP60), internal transcribed spacer (ITS)-5.8S ribosomal DNA (rDNA), nuclear large-subunit 28S rDNA (LSU), and RNA polymerase II second largest subunit (RPB2). Because not all the DNA regions were informative for differentiating all the fungal species observed, the DNA regions sequenced for each mycelial type were chosen based on previous phylogenetic analyses from taxonomic studies for the fungal genera observed (i.e., Athelia-like, Botrytis, Fusarium, Mucor, Neonectria, Penicillium, Phoma, Rhizopus, Sarocladium, and Talaromyces spp.; $3-5,18,20,21,25,35,39,43,53,55,59,63)$. The isolates were each grown in potato dextrose broth (PDB; Becton Dickinson \& Co.) on a DS-500E orbital shaker (VWR International, LLC, Aurora, CO; $100 \mathrm{rpm}$ ) at $21^{\circ} \mathrm{C}$ until a ball of mycelium (approximately $10 \mathrm{~mm}$ in diameter) was generated from the original 5-mm-diameter agar plug. The PDB was decanted and the tissue placed in a sterilized 2-ml microcentrifuge tube and stored at $-80^{\circ} \mathrm{C}$. Frozen tissue in individual tubes was freeze dried and then pulverized using a Retch MM301 mixer mill (Retch Inc., Newton, PA) with 5-mm-diameter stainless steel beads. DNA was extracted using a DNeasy Plant Mini Isolation Kit (Qiagen Inc., Valencia, CA) following standard protocols suggested by the manufacturer. The DNA was stored at $-20^{\circ} \mathrm{C}$.

Polymerase chain reaction (PCR) assays were performed in volumes of $30 \mu \mathrm{l}$ in accordance with the manufacturer's instructions: $10.8 \mu \mathrm{l}$ of molecular-grade water (5 Prime Inc., Gaithersburg, MD), $6 \mu \mathrm{l}$ of $5 \times$ PCR GoTaq buffer (Promega Corp., Madison, WI), $2.7 \mu \mathrm{l}$ of $25 \mathrm{mM} \mathrm{MgCl} 2$ (Applied Biosystems, Foster City, $\mathrm{CA}$ ), $3 \mu \mathrm{l}$ of $3 \mu \mathrm{M}$ each primer (Integrated DNA Technologies, Coralville, IA), $0.25 \mu$ l of GoTaq Taq DNA polymerase (Promega Corp.), and $2 \mu \mathrm{l}$ (approximately $60 \mathrm{ng}$ ) of target DNA. The amplification cycle consisted of $3 \mathrm{~min}$ at $95^{\circ} \mathrm{C}$ followed by 40 cycles of $95^{\circ} \mathrm{C}$ for $35 \mathrm{~s}$, the appropriate annealing temperature for $50 \mathrm{~s}$, and $72^{\circ} \mathrm{C}$ for $90 \mathrm{~s}$. The primer sequences and annealing temperatures are detailed in Table 1. Amplification products were electrophoresed through agarose gels $(1.8 \% \mathrm{wt} / \mathrm{vol})$ supplemented with ethidium bromide $(0.01 \mathrm{mg} / \mathrm{ml})$ in Tris-borate EDTA buffer $(89 \mathrm{mM}$ Tris base, $89 \mathrm{mM}$ boric acid, and $2 \mathrm{mM}$ EDTA). Amplicons were sent to TACGen (Richmond, CA) for PCR cleanup to remove excess dNTPs and unincorporated primers, and sequenced in both directions. Sequences were evaluated using BioEdit version 7.1.3.0 (24), consensus sequences were generated, and representative haplotypes were submitted to GenBank (accession numbers KM249066 to KM249138; Supplementary Table S1).
The Fusarium isolate sequences were submitted to the FUSARIUM MLST database (35) to facilitate identification. The sequences for other genera were compared with accessions in GenBank to confirm species identity using BLASTn 2.2.28 (2). A sequence was considered a match if the sequence had 97 to $100 \%$ sequence identity with accessions from published studies, with preference given to type strains and taxonomic studies. If an isolate failed these criteria or had 97 to $100 \%$ sequence identity with multiple species using BLASTn, phylogenetic analyses were conducted with a concatenated dataset. GenBank accessions for species of interest and closely related species were included in the phylogenetic analysis. DNA sequences were aligned using ClustalX version 2.0 (28). The maximum parsimony analysis was performed using PAUP with the heuristic search, simple taxon addition sequences, tree bisection-reconnection branch swapping, and MaxTrees = 100. Statistical support for the analyses was determined by bootstrap values for 1,000 replicates. MEGA 6.05 (54) was used to determine the substitution model that best fit the data according to the Bayesian Information Criterion. Maximum likelihood analyses were conducted with MEGA with an initial search (two replicates) used to estimate the model parameters. The parameters were then fixed for a bootstrap analysis of 1,000 replicates. The Bayesian phylogenetic analyses were conducted with MrBayes 3.2.1 (41), with the searches run until the standard deviation of split frequencies fell $<0.01$ (usually 80,000 to 200,000 generations). The analyses were conducted using the default priors. The majority-rule consensus was then calculated after removing the first $25 \%$ of generations as burn-in. The trees were visualized using FigTree (ver. 1.4; Institute of Evolutionary Biology, University of Edinburgh, Edinburgh, UK).

Data analysis. The SAS (version 9.2; SAS Institute Inc., Cary, NC) univariate procedure was used to test for normality of the data. Data were also subjected to analysis of variance using the SAS generalized linear mixed-models procedure (Proc GLIMMIX). In the model statement, the fixed effects included sampling time, field, and fungicide treatment. The random effects were block and any interaction terms with blocks. In the model statement, the denominator degrees of freedom were calculated using the DDFM=KENWARDRODGER option. Mean comparisons were conducted using least square means $(\alpha=0.05)$.

\section{Results}

Storage temperature. In 2012, the sugar beet storage building took 88 days to reach the $1.1^{\circ} \mathrm{C}$ set point (Fig. 1A). In 2013, the storage building took 66 days to reach the set point (Fig. 1B).

Table 1. Primers and annealing temperatures used to amplify DNA regions of fungi isolated from aerial mycelium and lesions on sugar beet roots held in a commercial storage building in Paul, ID during the 2012-13 and 2013 (G3PDH)14 storage seasons

\begin{tabular}{|c|c|c|c|}
\hline DNA region ${ }^{y}$ & Primer & Sequence & $\mathbf{T a}^{\mathbf{z}}$ \\
\hline \multirow[t]{2}{*}{ TUB } & TUB2Fd & 5'-GTBCACCTYCARACCGGYCARTG-3' & 52 \\
\hline & TUB4Rd & 5'-CCRGAYTGRCCRAARACRAAGTTGTC-3' & \\
\hline \multirow[t]{2}{*}{ G3PDH } & G3PDHfor & 5'-ATTGACATCGTCGCTGTCAACGA-3' & 64 \\
\hline & G3PDHrev & 5'-ACCCCACTCGTTGTCGTACCA-3' & \\
\hline \multirow[t]{2}{*}{ HSP60 } & HSP60for & 5'-CAACAATTGAGATTTGCCCACAAG-3' & 55 \\
\hline & HSP60rev & 5'-GATGGATCCAGTGGTACCGAGCAT-3' & \\
\hline \multirow[t]{2}{*}{ ITS-5.8S } & ITS1 & 5'-TCCGTAGGTGAACCTGCGG-3' & 62 \\
\hline & ITS4 & 5'-TCCTCCGCTTATTGATATGC-3' & \\
\hline \multirow[t]{5}{*}{ LSU } & 5.8SR & 5'-TCGATGAAGAACGCAGCG-3' & 52 \\
\hline & LR7 & 5'-TACTACCACCAAGATCT-3' & \\
\hline & LR0R & 5'-ACCCGCTGAACTTAAGC-3' & \\
\hline & LR5 & 5'-TCCTGAGGGAAACTTCG-3' & \\
\hline & LR3R & 5'-GTCTTGAAACACGGACC-3' & \\
\hline \multirow[t]{4}{*}{ RPB2 } & $5 f 2$ & 5'-GGGGWGAYCAGAAGAAGGC-3' & 55 \\
\hline & $7 \mathrm{cr}$ & 5'-CCCATRGCTTGYTTRCCCAT-3' & \\
\hline & $7 \mathrm{cf}$ & 5'-ATGGGYAARCAAGCYATGGG-3' & \\
\hline & $11 \mathrm{ar}$ & $5^{\prime}$-GCRTGGATCTTRTCRTCSACC-3' & \\
\hline
\end{tabular}

\footnotetext{
${ }^{y}$ Different DNA regions sequenced included $\beta$-tubulin (TUB) (4), glyceraldehyde-3-phosphate dehydrogenase (G3PDH) (45), heat-shock protein 60 (HSP60) (45), internal transcribed spacer (ITS)-5.8S ribosomal DNA (rDNA) (60), nuclear large-subunit 28S rDNA (LSU) (58), and RNA polymerase II second largest subunit (RPB2) $(30,36,40)$.

${ }^{\mathrm{z}} \mathrm{Ta}=$ annealing temperature $\left({ }^{\circ} \mathrm{C}\right)$.
} 
Beet root surface fungal growth. For the January 2013 ratings of the 2012 field season roots, the roots collected at different weeks after harvest had significantly $(P<0.0001)$ different ratings for root surface fungal growth; therefore, these data were analyzed separately by week of sampling (Table 2). The overall fungicide treatment means by week were $16,6,6,1$, and $0 \%$ surface area of the roots covered with fungal growth for weeks 1 through 5 , respectively. The fungicide and field main effects were significant at times (for fungicide weeks 1 to $5, P<0.0001,0.0006,0.0001,0.0504$, and 0.1749 , respectively; for field weeks 1 to $5, P=0.0004,0.0650,0.5428$, 0.5933 , and 0.8197 , respectively) but the interaction term was not significant for weeks $1(P=0.0924), 2(P=0.5575), 3$ ( $P=$ $0.0656), 4(P=0.8921)$, and $5(P=0.8013)$. In January 2013 for
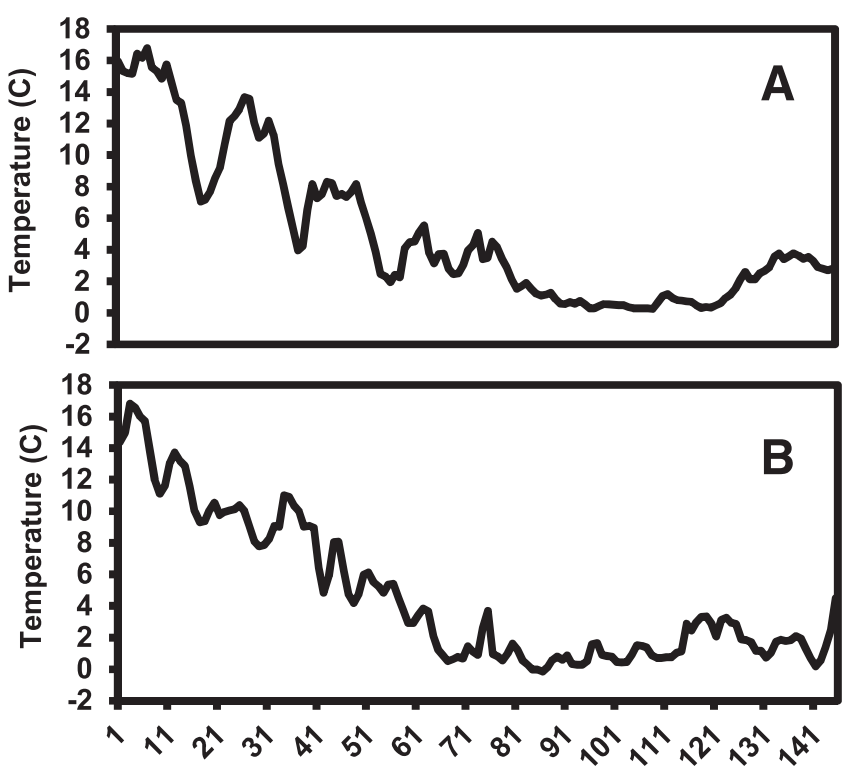

Days in storage

Fig. 1. Average daily temperature $\left({ }^{\circ} \mathrm{C}\right)$ in a commercial sugar beet pile $\mathbf{A}$, from 19 September 2012 to 13 February 2013 (148 days) for roots harvested in 2012 and B, from 18 September 2013 to 10 February 2014 (145 days) for roots harvested in 2013 in an indoor storage facility in Paul, ID. the first 3 weeks of root sampling, there were significant differences $(P<0.0001$ to 0.0006$)$ among fungicide treatments, with Stadium and Propulse reducing fungal growth by 84 to $100 \%$ compared with the nontreated control roots. In week 1 , these two fungicides reduced fungal growth by 81 and $96 \%$, respectively, compared with Mertect. Mertect did not affect fungal growth significantly compared with the control roots in week 1 but did reduce fungal growth by 47 and $67 \%$ compared with the control roots in the two subsequent weeks. During weeks 4 and 5, there were no significant differences among fungicide treatments $(P=0.0504$ and 0.1749 , respectively) because of the minimal fungal growth observed on the roots. In January 2013, roots from the field with a high incidence of BNYVV had $25 \%$ mean root surface area, with fungal growth which only differed $(P=0.0004)$ from that of the field with low BNYVV incidence (7\% surface area with fungal growth) in week 1 (data not shown). With roots sampled the other 4 weeks, fungal growth ranged from 0 to $9 \%$ of the root surface area with no significant differences for the main effect of fungicides $(P=0.0650$ to 0.8197$)$.

For the January 2014 ratings of the 2013 field season roots, the roots collected at different weeks had significantly $(P<0.0001)$ different ratings for fungal growth on the root surface; therefore, the data were analyzed separately by week of sampling (Table 2). The overall fungicide treatment means were $5,1,1,1$, and $1 \%$ root surface area with fungal growth for weeks 1 through 5 , respectively. The fungicide and field main effects were significant but the interaction term was not significant for weeks $1(P=0.2856), 2(P=0.1923), 3(P=$ $0.2200), 4(P=0.7950)$, and $5(P=0.1895)$. For 4 of the 5 weeks of sampling, the root surface area among fungicide treatments with fungal growth measured in January 2014 was significantly different ( $P<0.0001$ to 0.0150 ), with Stadium and Propulse reducing fungal growth by $100 \%$ compared with the nontreated roots. For week 1 roots, these treatments also reduced fungal growth $100 \%$ compared with the Mertect-treated roots. Mertect did not affect fungal growth significantly compared with the control roots in weeks 1,3 , and 4 but did reduce fungal growth by 67 and $50 \%$ compared with the control roots in weeks 2 and 5, respectively. For week 4 roots, there was no significant difference $(P=0.0860)$ among fungicide treatments. In January 2014 , roots from the field with high BNYVV incidence had only $2 \%$ fungal growth, which only differed significantly $(P=0.0295)$ from that of the field with low BNYVV incidence (1\% fungal growth) in week 2 (data not shown). Fungal growth on the roots sampled the other weeks only ranged from 0 to $6 \%$, which did not allow for differentiation

Table 2. Percentage of sugar beet root surface covered with fungal growth for the cultivar B-5 harvested at weekly intervals over a 5-week period and subjected to one of four treatments (no fungicide or one of three fungicides) in each of 2012 and 2013 in Idaho ${ }^{x}$

\begin{tabular}{|c|c|c|c|c|c|c|c|c|c|c|}
\hline \multirow[b]{2}{*}{ Treatment $^{\mathbf{y}}$} & \multicolumn{5}{|c|}{ January ratings } & \multicolumn{5}{|c|}{ February ratings } \\
\hline & 1 & 2 & 3 & 4 & 5 & 1 & 2 & 3 & 4 & 5 \\
\hline \multicolumn{11}{|l|}{2012 roots } \\
\hline Control & $32 \mathrm{a}$ & $15 \mathrm{a}$ & $18 \mathrm{a}$ & 3 & 1 & $51 \mathrm{a}$ & $23 \mathrm{a}$ & $28 \mathrm{a}$ & $8 \mathrm{a}$ & $2 \mathrm{a}$ \\
\hline Mertect & $27 \mathrm{a}$ & $8 \mathrm{~b}$ & $6 \mathrm{~b}$ & 1 & 0 & $43 \mathrm{a}$ & $14 \mathrm{a}$ & $18 \mathrm{~b}$ & $5 \mathrm{ab}$ & $2 \mathrm{a}$ \\
\hline Stadium & $5 \mathrm{~b}$ & $2 \mathrm{bc}$ & $0 \mathrm{~b}$ & 0 & 0 & $6 \mathrm{~b}$ & $2 \mathrm{~b}$ & $1 \mathrm{c}$ & $1 \mathrm{bc}$ & $1 \mathrm{ab}$ \\
\hline Propulse & $1 \mathrm{~b}$ & $1 \mathrm{c}$ & $0 \mathrm{~b}$ & 0 & 0 & $2 b$ & $1 \mathrm{~b}$ & $0 \mathrm{c}$ & $1 \mathrm{c}$ & $0 \mathrm{~b}$ \\
\hline$P>F^{\mathrm{z}}$ & $<0.0001$ & 0.0006 & $<0.0001$ & 0.0504 & 0.1749 & $<0.0001$ & 0.0008 & $<0.0001$ & $<0.0001$ & 0.0369 \\
\hline \multicolumn{11}{|l|}{2013 roots } \\
\hline Control & $11 \mathrm{a}$ & $3 a$ & $2 \mathrm{a}$ & 2 & $2 \mathrm{a}$ & $14 \mathrm{a}$ & $5 \mathrm{a}$ & $6 \mathrm{a}$ & $4 \mathrm{a}$ & $5 \mathrm{a}$ \\
\hline Mertect & $7 \mathrm{a}$ & $1 \mathrm{~b}$ & $1 \mathrm{ab}$ & 2 & $1 \mathrm{~b}$ & $12 \mathrm{a}$ & $2 \mathrm{a}$ & $2 \mathrm{~b}$ & $3 \mathrm{a}$ & $2 \mathrm{~b}$ \\
\hline Stadium & $0 \mathrm{~b}$ & $0 \mathrm{~b}$ & $0 \mathrm{~b}$ & 0 & $0 \mathrm{~b}$ & $1 \mathrm{~b}$ & $0 \mathrm{~b}$ & $0 \mathrm{~b}$ & $0 \mathrm{~b}$ & $0 \mathrm{~b}$ \\
\hline Propulse & $0 \mathrm{~b}$ & $0 \mathrm{~b}$ & $0 \mathrm{~b}$ & 0 & $0 \mathrm{~b}$ & $2 \mathrm{~b}$ & $0 \mathrm{~b}$ & $1 \mathrm{~b}$ & $1 \mathrm{~b}$ & $1 \mathrm{~b}$ \\
\hline$P>F$ & 0.0002 & $<0.0001$ & 0.0150 & 0.0860 & 0.0026 & $<0.0001$ & 0.0008 & $<0.0001$ & 0.0012 & 0.0057 \\
\hline
\end{tabular}

x The 2012 roots were rated on 15 January 2013 and again on 7 February 2013. The 2013 roots were rated on 17 January 2014 and again on 5 February 2014. Numbers 1 to 5 represent the five weekly harvest dates. In 2012, these were $1=19$ September, $2=26$ September, $3=3$ October, $4=10$ October, and $5=17$ October. In 2013, these were $1=18$ September, $2=25$ September, $3=4$ October, $4=9$ October, and $5=16$ October.

y Four treatments included control $=$ roots treated with water, Mertect $=$ Mertect 340F (42.3\% thiabendazole [vol/vol]; Syngenta Crop Protection, LLC, Greensboro, NC) applied with $\mathrm{ml}$ at 0.065 product $/ \mathrm{kg}$ of roots, Stadium = Stadium (12.51\% azoxystrobin, $12.51 \%$ fludioxonil, and $9.76 \%$ difenoconozole [vol/vol]; Syngenta Crop Protection, LLC) applied with product at $0.13 \mathrm{ml} / \mathrm{kg}$ of roots, and Propulse = Propulse (17.4\% fluopyram and $17.4 \%$ prothioconazole [vol/vol]; Bayer CropScience, Research Triangle Park, NC) applied with product at $0.049 \mathrm{ml} / \mathrm{kg}$ of roots. Each fungicide was applied in water at $8.34 \mathrm{ml} / \mathrm{kg}$ of roots.

${ }^{z} P>F=$ probability associated with the $F$ value in the analysis of variance using the SAS (SAS Institute, Inc., Cary, NC) generalized linear mixed-models procedure (Proc GLIMMIX). For each year, means followed by the same letter within a column did not differ significantly based on the least square means comparison $(\alpha=0.05)$. The experimental design each week was a randomized complete block with six replications. 
statistically ( $P=0.1859$ to 0.8424$)$ of fungicide treatment effects on fungal growth.

For the February 2013 ratings of the 2012 field season roots, the roots collected at different weeks in the field had significantly different fungal growth ratings $(P<0.0001)$; therefore, the data were analyzed separately by week (Table 2 ). The overall fungicide treatment means by week were $26,10,12,4$, and $1 \%$ of the root surface area with fungal growth for weeks 1 through 5 , respectively. The interaction of fungicide treatments and fields was not significant for weeks $2(P=0.6507), 3(P=0.5804), 4(P=0.4427)$, and $5(P=$ $0.9281)$. For week 1 roots, there was a significant interaction term $(P<0.0001)$ as a result of differences in magnitude of fungal growth among fungicide treatments and fields. However, because the rank of treatment means did not differ significantly between fields in week 1 , main effects of fungicide treatments were evaluated for week 1. There were significant differences $(P<0.0001$ to 0.0369$)$ among fungicide treatments, with Stadium and Propulse reducing fungal growth by 88 to $100 \%$ compared with the control roots over the first 4 weeks of sampling, and by 86 to $100 \%$ compared with Mertect-treated roots for the first 3 weeks of sampling (Table 2). Fungal growth only ranged from 0 to $1 \%$ for roots sampled in week 5 , which resulted

Table 3. Fungi observed on the surface of sugar beet roots and isolated from aerial mycelium as well as discolored tissue under root surface lesions of the cultivar B-5 grown in Idaho in 2012 and 2013, after the roots were stored in an indoor commercial storage facility

\begin{tabular}{|c|c|c|c|c|c|}
\hline \multirow[b]{3}{*}{ Fungus $^{\mathbf{y}}$} & \multirow{2}{*}{\multicolumn{2}{|c|}{$\begin{array}{c}\text { Primary aerial } \\
\text { mycelium }(\%)\end{array}$}} & \multicolumn{3}{|c|}{ Isolation incidence $(\%)^{x}$} \\
\hline & & & \multirow{2}{*}{$\begin{array}{c}\text { Aerial } \\
\text { mycelium }\end{array}$} & \multicolumn{2}{|c|}{$\begin{array}{c}\text { Root } \\
\text { lesions }\end{array}$} \\
\hline & Incidence & $\overline{\operatorname{Area}^{z}}$ & & $\overline{22^{\circ} \mathrm{C}}$ & $\overline{4^{\circ} \mathrm{C}}$ \\
\hline \multicolumn{6}{|l|}{2012 roots } \\
\hline Athelia-like sp. & 53 & $34 \pm 28$ & 20 & 10 & 10 \\
\hline Botrytis cinerea & 34 & $23 \pm 12$ & 20 & 19 & 24 \\
\hline Cladosporium spp. & 0 & NA & 0 & 0 & 0 \\
\hline Fusarium tricinctum & 0 & NA & 0 & 11 & 6 \\
\hline Mисоr sp. & 0 & NA & 0 & 1 & 1 \\
\hline $\begin{array}{l}\text { Neonectria } \\
\text { ramulariae }\end{array}$ & 0 & NA & 0 & 0 & 4 \\
\hline Penicillium spp. & 13 & $9 \pm 12$ & 53 & 25 & 27 \\
\hline Phoma betae & 0 & NA & 0 & 24 & 18 \\
\hline Rhizopus arrhizus & 0 & NA & 7 & 1 & 1 \\
\hline Sarocladium strictum & 0 & NA & 0 & 0 & 0 \\
\hline $\begin{array}{c}\text { Talaromyces } \\
\text { rugulosus }\end{array}$ & 0 & NA & 0 & 1 & 1 \\
\hline Yeast & NA & NA & NA & 8 & 8 \\
\hline \multicolumn{6}{|l|}{2013 roots } \\
\hline Athelia-like sp. & 36 & $8 \pm 5$ & 5 & 5 & 7 \\
\hline B. cinerea & 25 & $7 \pm 6$ & 33 & 43 & 42 \\
\hline Cladosporium spp. & 2 & $2 \pm 1$ & 15 & 0 & 0 \\
\hline F. tricinctum & 0 & NA & 0 & 1 & 3 \\
\hline Mucor sp. & 1 & $<1$ & 0 & 0 & 0 \\
\hline N. ramulariae & 0 & NA & 0 & 2 & 4 \\
\hline Penicillium spp. & 35 & $2 \pm 1$ & 47 & 30 & 31 \\
\hline P. betae & 0 & NA & 0 & 13 & 11 \\
\hline R. arrhizus & 1 & $<1$ & 0 & 0 & 0 \\
\hline S. strictum & 0 & NA & 0 & 2 & 0 \\
\hline T. rugulosus & 0 & NA & 0 & 0 & 0 \\
\hline Yeast & NA & NA & 0 & 4 & 2 \\
\hline
\end{tabular}

${ }^{x}$ Five arbitrarily chosen patches of aerial mycelium from each fungal morphology type from each set of roots. Isolations from root lesions (for up to five arbitrarily chosen roots with surface discoloration by treatment and week of sampling, where possible) were incubated at both 4 and $22^{\circ} \mathrm{C}$ from the same root tissue.

y Fungi isolated from aerial mycelium and internal root tissue under surface lesions observed on sugar beet roots stored in an indoor commercial storage building. The Athelia-like sp. was described previously by Toda et al. (55).

${ }^{\mathrm{z}}$ Mean root surface area (\%) covered by fungal growth in storage on 7 February 2013 (2012 harvested roots) and 5 February 2014 (2013 harvested roots). Each value is the mean \pm standard deviation of 25 replicate samples. $\mathrm{NA}=$ not applicable. in poor treatment separation statistically. Mertect was only better than the control treatment in terms of reducing fungal growth for roots sampled in week 3. For the February 2013 ratings, roots sampled from the field with high BNYVV incidence averaged $40 \%$ fungal growth, which only differed significantly $(P<0.0001)$ from that of the low-incidence field (10\% fungal growth) in week 1 (data not shown). For roots sampled at the other 4 weeks, surface fungal growth ranged from 1 to $13 \%$, with no significant differences among the fungicide treatments $(P=0.1911$ to 0.8108$)$.

For the February 2014 ratings of the 2013 field season roots, the roots collected at different weeks had significantly $(P<0.0001)$ different fungal growth ratings; therefore, the data were analyzed separately by week. The overall fungicide treatment means by week were $7,2,2,2$, and $2 \%$ surface area with fungal growth for weeks 1 through 5, respectively. The interaction of fungicide treatments and fields was not significant for weeks $1(P=0.1451), 2(P=$ $0.9260), 4(P=0.7865)$, and $5(P=0.6499)$ but there was a significant interaction in week $3(P=0.0046)$ as a result of differences in magnitude of fungal growth among fungicide treatments and fields sampled. Because the rank of treatment means between fields did not differ significantly, the fungicide and field main effects were calculated for week 3 . There were significant differences $(P<0.0001$ to $0.0057)$ among fungicide treatments, with Stadium and Propulse reducing fungal growth by 75 to $100 \%$ compared with the control roots over the 5 weeks of sampling, and by 67 to $100 \%$ compared with Mertect-treated roots during three of the 5 weeks of sampling (Table 2). Mertect reduced fungal growth significantly (60 to 67\%) compared with the control roots in 2 of the 5 weeks of sampling. Roots from the fields with high and low BNYVV incidence did not differ significantly ( $P=0.0559$ to 0.3116$)$ in mean fungal growth, which ranged from 1 to $8 \%$ (data not shown).

Based on visual observations in both years, the three primary types of fungi responsible for producing aerial mycelium on the roots were an Athelia-like sp., Botrytis cinerea Pers., and Penicillium spp. (Table 3). The root surface area covered with mycelium ranged from 2 to $34 \%$ depending on the fungus and year but the Athelia-like sp. ranked first in both years for incidence and area of root surface covered. The incidence of roots with mycelium in the 2012 low-BNYVV field for the Athelia-like sp., B. cinerea, and Penicillium spp. was 49, 40 , and $11 \%$, respectively; whereas the incidence in the high-BNYVV field was 56, 29, and 15\%, respectively. The incidence in the 2013 low-BNYVV field of roots with mycelium of the Athelia-like sp., B. cinerea, and Penicillium spp. was 39, 28, and 33\%, respectively; whereas the incidence in the high-BNYVV field was 33, 24, and $40 \%$, respectively. In addition to these species in the field with high incidence BNYVV, there was a $2 \%$ incidence of Cladosporium spp.

In 2012, the average percent root surface area covered by any one species was 5 to $18 \%$ for the low-BNYVV field, while the range for the high-BNYVV field was 4 to $46 \%$. However, there were no significant differences in prevalence among fungal species based on means and standard deviations. In 2013, the average percent root surface area covered by any one fungal species was 3 to $9 \%$ for the low-BNYVV field, while the range for the high-BNYVV field was 2 to $10 \%$. However, there were no significant differences in prevalence among fungal species based on means and standard deviations.

Root surface discoloration. The 2012 roots collected at different weeks after harvest had significantly $(P<0.0001)$ different root surface discoloration ratings; therefore, the data were analyzed separately by week. The overall fungicide main effect means by week were $9,5,8,2$, and $1 \%$ surface discoloration for weeks 1 through 5 , respectively. The interaction of fungicide treatments and fields was not significant for weeks $1(P=0.4430), 2(P=0.4413), 3$ $(P=0.9993), 4(P=0.6920)$, and $5(P=0.7174)$. There were significant differences in surface discoloration among fungicide treatments for roots sampled each week $(P<0.0001$ to 0.0125$)$. When compared with the control roots, there was 75 to $100 \%$ less surface discoloration on roots treated with Propulse and Stadium across all 5 weeks, except for roots treated with Stadium that were collected in week 1 (Table 4). Compared with Mertect-treated roots, there was 64 to 
$100 \%$ less surface discoloration on roots treated with Propulse and Stadium that had been harvested the first 3 weeks but there were no significant differences in weeks 4 and 5 . The roots from the field with high BNYVV incidence averaged $13 \%$ surface discoloration, which differed significantly $(P=0.0015)$ from that of the lowBNYVV-incidence field (4\% surface discoloration) in week 1 (data not shown). For week 2 roots, roots from the field with high BNYVV incidence (6\% surface discoloration) also differed $(P=0.0299)$ from the field with low BNYVV incidence (3\% discoloration). For roots harvested in the subsequent 3 weeks, surface discoloration only ranged from 1 to $8 \%$ with no significant differences between the two fields with different incidences of BNYVV $(P=0.0592$ to 0.9118).

The 2013 roots collected at different weeks after harvest had significantly $(P<0.0001)$ different surface discoloration ratings; therefore, the data were analyzed separately by week. The overall fungicide treatment means by week were $4,2,2,3$, and $2 \%$ discoloration of the roots for weeks 1 through 5, respectively. The interaction of fungicide treatments and fields was not significant for weeks 1 $(P=0.4196), 2(P=0.8101), 3(P=0.0969), 4(P=0.3701)$, and 5 $(P=0.8627)$. There were significant differences in root surface discoloration $(P<0.0001$ to 0.0006$)$ among fungicide treatments. Compared with the control roots, there was 75 to $100 \%$ less surface discoloration on roots treated with Propulse and Stadium across all 5 weeks (Table 4). Compared with Mertect-treated roots, there was 50 to $80 \%$ less surface discoloration on roots treated with Propulse and Stadium during weeks 1,3 , and 4 , while there were no significant differences in week 2 and only Propulse differed from Mertect in week 5. With discoloration ranging from only 1 to $5 \%$, roots from the field with high BNYVV incidence were not significantly different in discoloration from those from the field with low BNYVV incidence for 4 of

Table 4. Percentage of sugar beet root surface area discolored for the cultivar B-5 harvested at weekly intervals over a 5-week period and subjected to one of four treatments (no fungicide or one of three fungicides) in 2012 and 2013 in Idaho

\begin{tabular}{lccccc}
\hline & \multicolumn{5}{c}{ Week of root harvest } \\
\cline { 2 - 6 } Treatment $^{\mathbf{y}}$ & $\mathbf{1}$ & $\mathbf{2}$ & $\mathbf{3}$ & $\mathbf{4}$ & $\mathbf{5}$ \\
\hline $\mathbf{2 0 1 2}$ roots & & & & & \\
Control & $12 \mathrm{ab}$ & $8 \mathrm{a}$ & $20 \mathrm{a}$ & $4 \mathrm{a}$ & $4 \mathrm{a}$ \\
Mertect & $14 \mathrm{a}$ & $8 \mathrm{a}$ & $9 \mathrm{~b}$ & $2 \mathrm{~b}$ & $2 \mathrm{ab}$ \\
Stadium & $5 \mathrm{bc}$ & $2 \mathrm{~b}$ & $1 \mathrm{c}$ & $0 \mathrm{~b}$ & $0 \mathrm{~b}$ \\
Propulse & $3 \mathrm{c}$ & $1 \mathrm{~b}$ & $0 \mathrm{c}$ & $0 \mathrm{~b}$ & $0 \mathrm{~b}$ \\
$P>F^{\mathbf{z}}$ & 0.0125 & 0.0009 & $<0.0001$ & 0.0007 & 0.0080 \\
$\mathbf{2 0 1 3}$ roots & & & & & \\
Control & $10 \mathrm{a}$ & $4 \mathrm{a}$ & $5 \mathrm{a}$ & $6 \mathrm{a}$ & $4 \mathrm{a}$ \\
Mertect & $5 \mathrm{~b}$ & $2 \mathrm{~b}$ & $2 \mathrm{~b}$ & $3 \mathrm{~b}$ & $2 \mathrm{~b}$ \\
Stadium & $1 \mathrm{c}$ & $1 \mathrm{~b}$ & $1 \mathrm{c}$ & $1 \mathrm{c}$ & $1 \mathrm{bc}$ \\
Propulse & $2 \mathrm{c}$ & $0 \mathrm{~b}$ & $1 \mathrm{c}$ & $1 \mathrm{c}$ & $0 \mathrm{c}$ \\
$P>F$ & $<0.0001$ & 0.0006 & $<0.0001$ & $<0.0001$ & $<0.0001$ \\
\hline
\end{tabular}

y Four treatments included control $=$ roots treated with water, Mertect $=$ Mertect $340 \mathrm{~F}$ ( $42.3 \%$ thiabendazole [vol/vol]; Syngenta Crop Protection, LLC, Greensboro, NC) applied with product at $0.065 \mathrm{ml} / \mathrm{kg}$ of roots, Stadium = Stadium (12.51\% azoxystrobin, $12.51 \%$ fludioxonil, and $9.76 \%$ difenoconozole [vol/vol]; Syngenta Crop Protection, LLC) applied with product at $0.13 \mathrm{ml} / \mathrm{kg}$ of roots, and Propulse $=$ Propulse $(17.4 \%$ fluopyram and $17.4 \%$ prothioconazole [vol/vol]; Bayer CropScience, Research Triangle Park, NC) applied with product at $0.049 \mathrm{ml} / \mathrm{kg}$ of roots. Each fungicide was applied in water at $8.34 \mathrm{ml} / \mathrm{kg}$ of roots. Numbers 1 to 5 represent the five weekly harvest dates. In 2012, these were $1=19$ September, $2=26$ September, $3=3$ October, $4=10$ October, and $5=17$ October. In 2013, these were $1=18$ September, $2=25$ September, $3=4$ October, $4=9$ October, and $5=16$ October. The 2012 roots were rated on 13 February 2013. The 2013 roots were rated on 10 February 2014.

${ }^{z} P>F=$ probability associated with the $F$ value in the analysis of variance when using the SAS (SAS Institute, Inc., Cary, NC) generalized mixedmodels procedure (Proc GLIMMIX). For each year, means followed by the same letter within a column did not differ significantly based on the least square means comparison $(\alpha=0.05)$. The experimental design each week was a randomized complete block with six replications. the 5 weeks sampled ( $P=0.2179$ to 0.5566 ) (data not shown). Week 3 results indicated the $3 \%$ average root surface discoloration associated with the field with low BNYVV incidence was greater $(P=$ $0.0054)$ than the $1 \%$ average discoloration associated with roots from the field with high BNYVV incidence.

Root weight loss. The 2012 roots collected from the field on different weeks had significantly $(P<0.0001)$ different levels of weight loss measured after 148 (week 1 roots) to 120 (week 5 roots) days in storage; therefore, the data were analyzed separately by week. The overall fungicide treatment means for root weight loss by week were $10,8,8,4$, and $5 \%$ for roots collected in weeks 1 through 5 , respectively. The fungicide-field interaction term was not significant for weeks 1 ( $P=0.1932), 2$ ( $P=0.2679), 3$ ( $P=0.6879), 4$ ( $P=$ $0.2258)$, and $5(P=0.2060)$. Although weight loss ranged from 4.3 to $10.2 \%$ across weeks (data not shown), there were no significant differences $(P=0.0630$ to 0.6515$)$ between fungicide treatments within weeks. When comparing the fields with high and low BNYVV incidence, there were significant differences in root weight loss for roots collected in week $1(P=0.0225)$, with $10.4 \%$ weight loss in the field with high BNYVV incidence and $8.6 \%$ in the field with low BNYVV incidence; and week $4(P=0.0004)$, with $5.0 \%$ weight loss in the field with high BNYVV incidence and $3.7 \%$ weight loss in the field with low BNYVV incidence (data not shown). Weight loss of roots sampled from these fields for the other 3 weeks ranged from 4.6 to $8.7 \%$, with no significant differences between fields $(P=0.0730$ to 0.4788$)$.

The 2013 roots collected on different weeks had significantly $(P<$ 0.0001 ) different levels of root weight loss; therefore, the data were analyzed separately by week of sampling. The overall fungicide treatment means for root weight loss by week were $7,7,7,6$, and $5 \%$ for weeks 1 through 5 , respectively. The fungicide-field interaction term was not significant for weeks $2(P=0.5417)$ and $4(P=$ 0.6276). For weeks 2 and 4 roots, there were no significant

Table 5. Percent sucrose loss in sugar beet roots of the cultivar B-5 harvested at weekly intervals over a 5-week period and subjected to one of four treatments (no fungicide or one of three fungicides) in 2012 and 2013 in Idaho

\begin{tabular}{lccccc}
\hline & \multicolumn{5}{c}{ Week of root harvest } \\
\cline { 2 - 6 } Treatment $^{y}$ & $\mathbf{1}$ & $\mathbf{2}$ & $\mathbf{3}$ & $\mathbf{4}$ & $\mathbf{5}$ \\
\hline 2012 roots & & & & \\
Control & $35.2 \mathrm{a}$ & $28.4 \mathrm{ab}$ & $33.1 \mathrm{a}$ & $24.1 \mathrm{a}$ & 18.1 \\
Mertect & $37.7 \mathrm{a}$ & $31.0 \mathrm{a}$ & $29.5 \mathrm{a}$ & $20.1 \mathrm{~b}$ & 17.8 \\
Stadium & $28.0 \mathrm{~b}$ & $21.5 \mathrm{c}$ & $21.0 \mathrm{~b}$ & $20.5 \mathrm{~b}$ & 17.1 \\
Propulse & $23.1 \mathrm{~b}$ & $23.9 \mathrm{bc}$ & $18.0 \mathrm{~b}$ & $18.4 \mathrm{~b}$ & 15.0 \\
$P>F^{z}$ & 0.0001 & 0.0018 & $<0.0001$ & 0.0128 & 0.4519 \\
2013 roots & & & & & \\
Control & $25.3 \mathrm{a}$ & $21.2 \mathrm{ab}$ & $19.2 \mathrm{a}$ & $19.5 \mathrm{a}$ & $19.0 \mathrm{a}$ \\
Mertect & $22.5 \mathrm{a}$ & $23.5 \mathrm{a}$ & $15.7 \mathrm{~b}$ & $18.7 \mathrm{a}$ & $16.9 \mathrm{~b}$ \\
Stadium & $15.7 \mathrm{~b}$ & $19.3 \mathrm{bc}$ & $15.9 \mathrm{~b}$ & $15.8 \mathrm{~b}$ & $16.4 \mathrm{~b}$ \\
Propulse & $17.6 \mathrm{~b}$ & $18.1 \mathrm{c}$ & $12.1 \mathrm{c}$ & $13.8 \mathrm{~b}$ & $15.7 \mathrm{~b}$ \\
$P>F$ & $<0.0001$ & 0.0006 & $<0.0001$ & $<0.0001$ & 0.0146 \\
\hline
\end{tabular}

y Four treatments included control = roots just treated with water, Mertect = Mertect 340F (42.3\% thiabendazole [vol/vol]; Syngenta Crop Protection, LLC, Greensboro, NC) applied with product at $0.065 \mathrm{ml} / \mathrm{kg}$ of roots, Stadium $=$ Stadium $(12.51 \%$ azoxystrobin, $12.51 \%$ fludioxonil, and $9.76 \%$ difenoconozole [vol/vol]; Syngenta Crop Protection, LLC) applied with product at $0.13 \mathrm{ml} / \mathrm{kg}$ of roots, and Propulse = Propulse $(17.4 \%$ fluopyram and $17.4 \%$ prothioconazole [vol/vol]; Bayer CropScience, Research Triangle Park, NC) with product at $0.049 \mathrm{ml} / \mathrm{kg}$ of roots. Each fungicide was applied in water at $8.34 \mathrm{ml} / \mathrm{kg}$ of roots. Numbers 1 to 5 represent the five weekly harvest dates. In 2012, these were $1=19$ September, $2=26$ September, $3=3$ October, $4=10$ October, and $5=17$ October. In 2013, these were $1=18$ September, $2=25$ September, $3=4$ October, $4=9$ October, and $5=$ 16 October

${ }^{\text {z }} P>F=$ probability associated with the $F$ value in the analysis of variance when using SAS (SAS Institute, Inc., Cary, NC) generalized mixed-models procedure (Proc GLIMMIX). For each year, means followed by the same letter within a column did not differ significantly based on the least square means comparison $(\alpha=0.05)$. The experimental design each week was a randomized complete block with six replications. 
differences among treatments for either of the main effects $(P=$ 0.0748 to 0.3562$)$. A significant interaction of fungicide treatments and fields was evident in weeks $1(P=0.0043), 3(P=0.0057)$, and $5(P=0.0212)$. For week 3 roots, fungicide treatments did not differ in effect on weight loss (6.7 to $7.3 \%$ loss, $P=0.7907)$ of roots from the field with low BNYVV incidence. However, roots from this low-incidence field did differ significantly in weight loss among fungicide treatments during weeks 1 (Mertect roots had the most weight

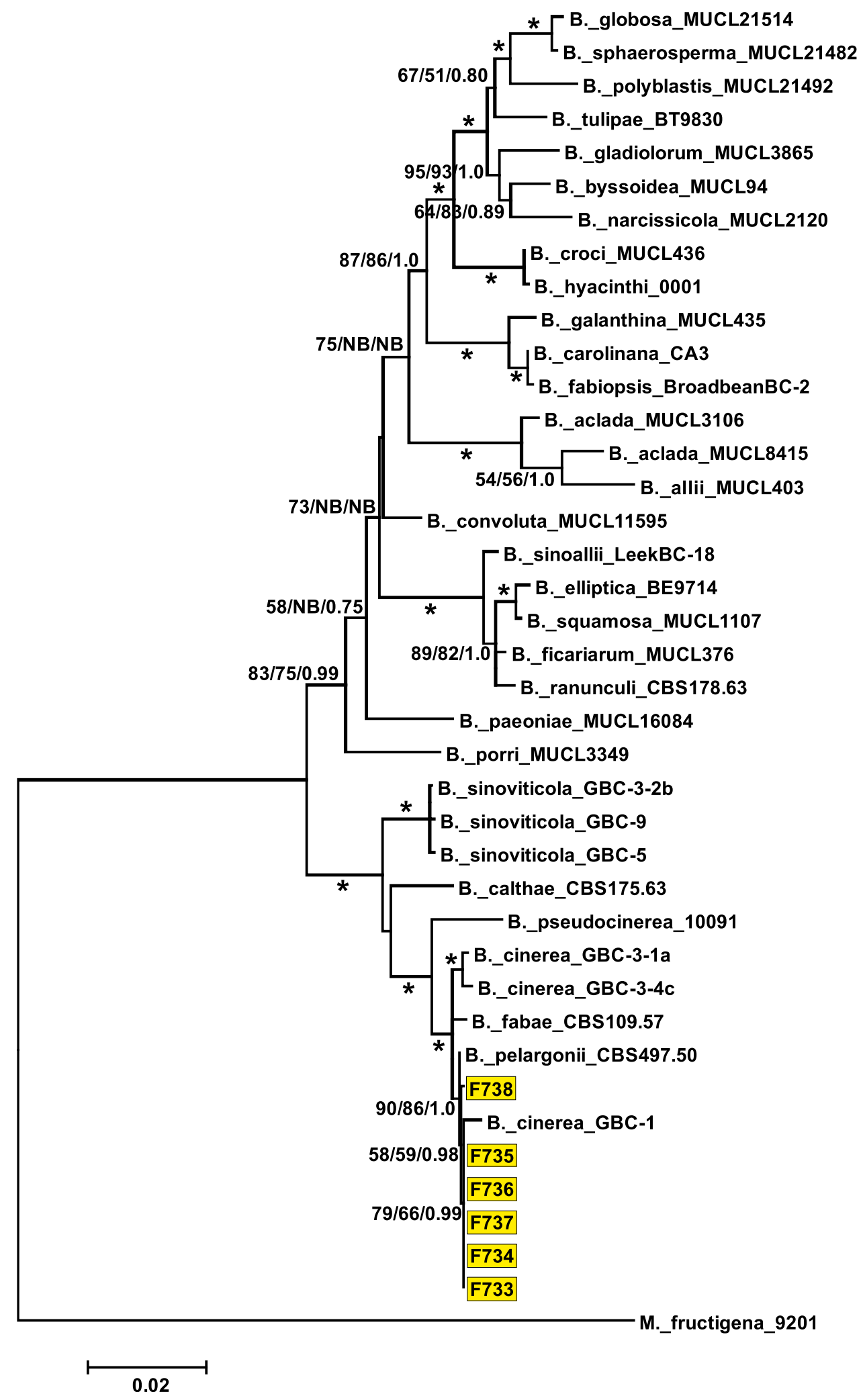

Fig. 2. Phylogenetic relationships among Botrytis spp. and six fungal isolates (F733 to F738, noted by the yellow boxes) collected from sugar beet roots in an Idaho commercial storage facility based on sequences of the RNA polymerase II, heat-shock protein 60, and glyceraldehyde-3-phosphate dehydrogenase regions of DNA. The length of the concatenated sequence was 2,774 nucleotides (nt), of which 2,152 nt were conserved, $622 \mathrm{nt}$ were variable, and $346 \mathrm{nt}$ were parsimony informative. Numbers on nodes represent the statistical support for maximum likelihood (ML; 1,000 replicates, left number), maximum parsimony (MP; 1,000 bootstrap replicates, middle number), and Bayesian method (posterior probabilities, right number). Asterisks indicate support of $\geq 95 \%$ for ML and MP and $\geq 0.95$ for the Bayesian method. NB indicates no branch detected in this analysis. Botrytis spp. sequences were obtained from GenBank and the species names are followed by strain designations. The tree was rooted to Monilinia fructigena strain 9201. 
loss at $9.5 \%$ ) and 5 (control roots had the most weight loss at $6.5 \%$ ) $(P=0.0435$ and 0.0188 , respectively). In the field with high BNYVV incidence, week 5 roots did not differ significantly in weight loss (5.0 to $5.4 \%)$ among the fungicide treatments $(P=0.7713)$. However, roots from this high-incidence field did differ significantly in weight loss among fungicide treatments during weeks 1 (control and Mertect-treated roots had the most loss, with 9.4 and $7.4 \%$, respectively) and 3 (Propulse, control, and Mertect roots had the most loss, with $7.9,7.5$, and $6.0 \%$, respectively) $(P=0.0015$ and 0.0017 , respectively). Although significant differences were detected at times among fungicide treatments, there was no consistent trend for one treatment to always result in the least weight loss. Root weight loss from the high- and low-incidence fields was also compared within each fungicide treatment. The control roots from the high- and low-incidence fields did not differ in weight loss which ranged from 7.3 to $9.4 \%$ in weeks $1(P=0.0516)$ and $3(P=0.6335)$. For week 5 control roots, roots from the field with low BNYVV incidence had $6.5 \%$ weight loss, which was greater $(P=0.0316)$ weight loss than

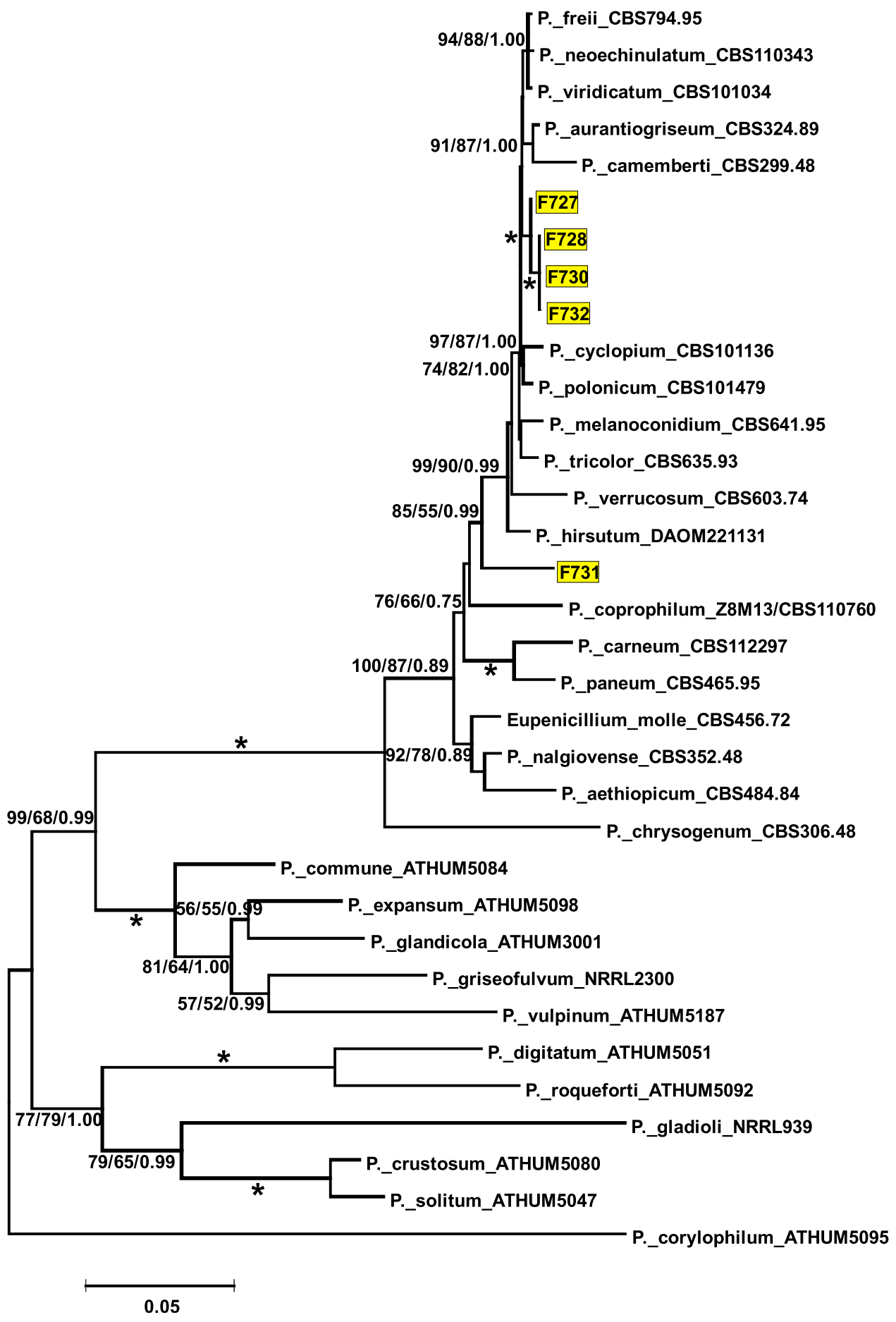

Fig. 3. Phylogenetic relationships among Penicillium spp. and five fungal isolates (F727, F728, F730, F731, and F732, noted by the yellow boxes) collected from sugar beet roots in an Idaho commercial storage facility based on concatenated sequences from the internal transcribed spacer-5.8S, 28S, $\beta$-tubulin, and RNA polymerase II regions of DNA. The length of the concatenated sequences was 2,570 nucleotides (nt), of which $864 \mathrm{nt}$ were conserved, 1,706 nt were variable, and $986 \mathrm{nt}$ were parsimony informative. Numbers on nodes represent the statistical support for maximum likelihood (ML; 1,000 replicates, left number), maximum parsimony (MP; 1,000 bootstrap replicates, middle number), and Bayesian method (posterior probabilities, right number). Asterisks indicate support of $\geq 95 \%$ for ML and MP and $\geq 0.95$ for the Bayesian method. Penicillium spp. sequences were obtained from GenBank and the species names are followed by strain designations. 
that of the control roots from the high-incidence field (5.1\%). In weeks 1 and 5 for Mertect-treated roots, the roots from the field with low BNYVV incidence had more weight loss $(9.5$ and $6.2 \%$, respectively) than roots from the high-incidence field ( 7.4 and $4.9 \%$, respectively) ( $P=0.0226$ and 0.0453 , respectively). For week 3 Mertect-treated roots, root weight loss (6.0 to 6.7\%) did not differ significantly $(P=0.4938)$ between the two fields. In weeks 1,3 , and 5 for the Propulse-treated roots, the roots from the two fields did not differ significantly $(P=0.0763$ to 0.1347$)$ in weight loss (4.0 to 7.9\%). In weeks 1 and 5 for the Stadium-treated roots, the roots from the two fields did not differ significantly $(P=0.0617$ and 0.4986 , respectively) in weight loss (ranged from 5.0 to $7.5 \%$ ). For week 3 Stadium-treated roots, weight loss $(6.8 \%)$ in roots from the field with low BNYVV incidence was greater $(P=0.0074)$ than the loss from the high-incidence field (3.5\%). In summary, roots sampled from the field with low BNYVV incidence lost more weight in comparison with roots from the high-incidence field when significant differences were evident, regardless of fungicide treatment.

Root sucrose loss. The 2012 roots collected at different weeks had significantly different levels of sucrose loss $(P<0.0001)$; therefore, the data were analyzed separately by week. The overall fungicide treatment means for sucrose loss from the roots sampled by week were $31,26,25,21$, and $17 \%$ for weeks 1 through 5 , respectively. The fungicide-field interaction term was not significant for weeks $1(P=0.1110), 2(P=0.1825), 3(P=0.5035), 4(P=0.8782)$, and $5(P=0.3920)$. In weeks 1,3 , and 4 , roots treated with Stadium and Propulse had 15 to $46 \%$ less sucrose loss compared with the control roots (Table 5). In week 2, Stadium-treated roots had $24 \%$ less sucrose loss compared with the control roots, while Propulsetreated roots did not differ significantly from the control roots in terms of sucrose loss (Table 5). There were no significant differences between the control roots and fungicide-treated roots in week 5 . Mertect treatment of roots only reduced sucrose loss significantly

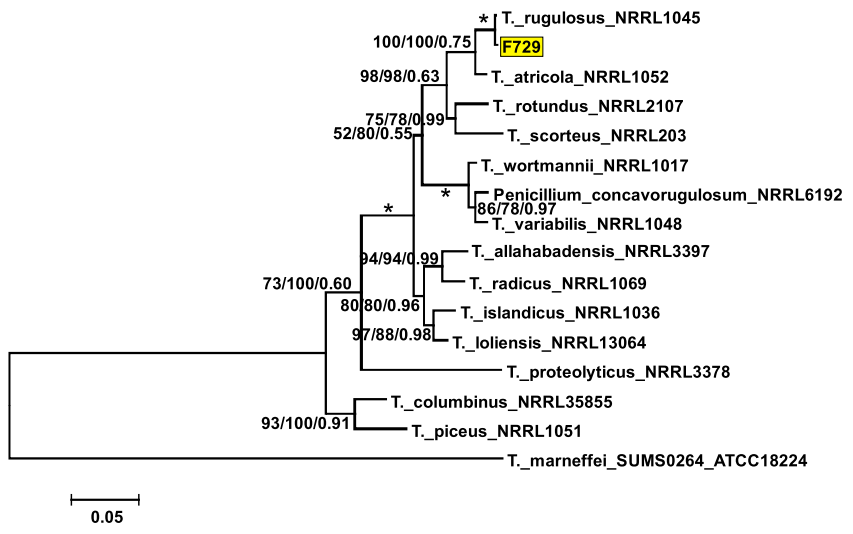

Fig. 4. Phylogenetic relationships among Talaromyces clade $2 \mathrm{~A}$ species and a fungal isolate (F729, noted by the yellow box) collected from sugar beet roots in an Idaho commercial storage facility based on the concatenated sequences from the internal transcribed spacer-5.8S and the RNA polymerase II DNA regions. The length of the concatenated sequences was 1,411 nucleotides (nt), of which $701 \mathrm{nt}$ were conserved, $710 \mathrm{nt}$ were variable, and $293 \mathrm{nt}$ were parsimony informative. Numbers on nodes represent the statistical support for maximum likelihood (ML; 1,000 replicates, left number), maximum parsimony (MP; 1,000 bootstrap replicates, middle number), and Bayesian method (posterior probabilities, right number). Asterisks indicate support of $\geq 95 \%$ for $\mathrm{ML}$ and MP and $\geq 0.95$ for the Bayesian method. Talaromyces spp. sequences were obtained from GenBank and the species names are followed by strain designations. compared with the control roots for those roots sampled in week 4. When compared across weeks, the Propulse-treated roots ranked first for less sucrose loss versus the other treatments, except for Stadiumtreated roots in week 2 . There was significantly more sucrose loss associated with the root samples from the field with high BNYVV incidence than the field with low BNYVV incidence in week $1(P<$ 0.0001 ), when roots from the high-incidence field averaged $39.0 \%$ sucrose loss versus $23 \%$ for roots from the low-incidence field; and week $3(P=0.0348)$, when roots from the high-incidence field averaged $27.3 \%$ and from the low-incidence field averaged $23.5 \%$. For roots collected in the other 3 weeks, sucrose loss was 16.4 to $27.7 \%$ but there were no significant differences between fields $(P=0.0951$ to 0.4370$)$ (data not shown).

The 2013 roots collected on different weeks had significantly $(P<$ 0.0001 ) different levels of sucrose loss; therefore, the data were analyzed separately by week of sampling. The overall fungicide treatment means for sucrose loss were $20,21,16,17$, and $17 \%$ for weeks 1 through 5 , respectively. The fungicide and field main effects were significant but the interaction term was not significant for weeks $1(P=0.0545), 2(P=0.3637), 3(P=0.1390), 4(P=0.3532)$, and $5(P=0.0552)$. In 4 of the 5 weeks, Stadium- and Propulse-treated roots had 14 to $38 \%$ less sucrose reduction compared with the control roots (Table 5). Application of these products resulted in 16 to $30 \%$ less sucrose reduction than the application of Mertect on roots sampled in weeks 1,2 , and 4 . Roots from the field with high BNYVV incidence had 12 to $21 \%$ greater sucrose reduction $(P<0.0001$ to 0.0146) than those from the field with low BNYVV incidence in weeks 3 through 5 but, in weeks 1 and 2, sucrose loss was only 19.9 to $20.7 \%$, with no significant differences between fields $(P=$ 0.5639 and 0.7856 , respectively) (data not shown).

Fungal isolations. In both years of this study, isolations from aerial mycelium on the sugar beet roots confirmed the presence of an Athelia-like sp., B. cinerea, and Penicillium spp., although Rhizopus arrhizus A. Fisch. was also detected on 2012 roots and Cladosporium spp. were also detected on 2013 roots (Table 3 ). Isolations from arbitrarily chosen root lesions confirmed the presence of these fungi along with Fusarium tricinctum (Corda) Sacc., a Mucor sp., Neonectria ramulariae Wollenw., Phoma betae A. B. Frank, Sarocladium strictum (W. Gams) Summerb., Talaromyces rugulosus (Thom) Samson, N. Yilmaz, Frisvad \& Seifert, and yeasts. Although not evident from the aerial mycelium alone, $P$. betae was among the more prevalent fungi isolated from discolored root tissue. All fungi isolated at an incubation temperature of $4^{\circ} \mathrm{C}$ were also isolated at $22^{\circ} \mathrm{C}$, with the exception of the Neonectria sp., which was isolated from the 2012 roots at $4^{\circ} \mathrm{C}$ only, and the Sarocladium sp., isolated from the 2013 roots at $22^{\circ} \mathrm{C}$ only (Table 3 ).

Molecular characterization. Six Athelia-like isolates (F721 to F726) were identified based on the ITS-5.8S rDNA sequence, of which five had $100 \%$ sequence identity (F722 = NRRL 62804; GenBank accession number KM249067.1) and 100\% sequence identity with GenBank accessions AB596010, AB596011, AB596012, AB596025, and KF742594. Isolate F721 (= NRRL 62803; KM249066.1) had one less nucleotide in the sequence than the other five isolates. Based on the LSU region, all six Athelia-like isolates (F721 to F726) had $100 \%$ sequence identity (consensus sequence KM249088.1) and $100 \%$ sequence identity with accessions AB596026 and AB596027.

Five of the six Botrytis isolates identified from the discolored sugar beet roots (F733 to F738) based on the ITS-5.8S region had 100\% sequence identity (F734; KM249074.1) with each other and primarily

Fig. 5. Phylogenetic relationships among Mucor spp. and two fungal isolates (F752 and F753, noted by the yellow boxes) collected from sugar beet roots in an Idaho commercial storage facility based on the concatenated sequences from the internal transcribed spacer-5.8S and the $28 \mathrm{~S}$ DNA regions. The length of the concatenated sequences was $1,486 \mathrm{nucleotides}$ (nt), of which $619 \mathrm{nt}$ were conserved, $867 \mathrm{nt}$ were variable, and $644 \mathrm{nt}$ were parsimony informative. Numbers on nodes represent the statistical support for maximum likelihood (ML; 1,000 replicates, left number), maximum parsimony (MP; 1,000 bootstrap replicates, middle number), and Bayesian method (posterior probabilities, right number). Asterisks indicate support of $\geq 95 \%$ for $\mathrm{ML}$ and MP and $\geq 0.95$ for the Bayesian method. Mucor spp. sequences were obtained from GenBank and the species names are followed by strain designations. NB indicates no branch was detected in this particular analysis. The tree was rooted to Rhizopus stolonifer strain CBS150.83 (GenBank accession numbers AB113022.1 and AB250199.1). 


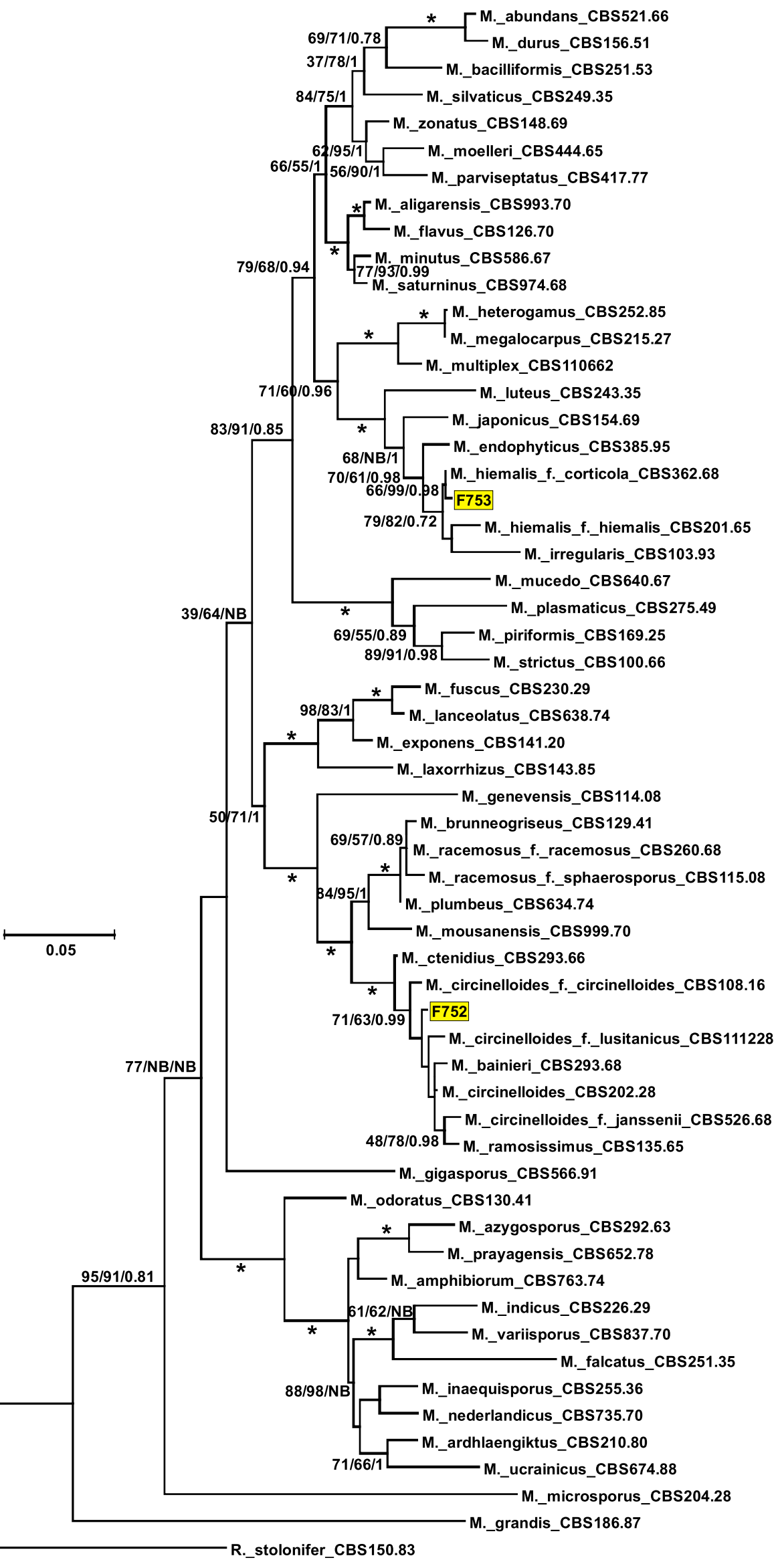


with B. cinerea GenBank accessions (JN692383, JN692373, JN692379, and so on). Isolate F733 (KM249073.1) had one nucleotide difference compared with the other five isolates. Based on the TUB sequences, all six isolates had $100 \%$ sequence identity with each other (KM249110.1) and with other B. cinerea strains in GenBank (FQ790278, HQ890461, JX535305, KC620302, U27198, and so on). Based on the LSU sequences, all six isolates had $100 \%$ sequence identity with each other (consensus sequence KM249092.1) and with B. cinerea accession JN938889. Based on the G3PDH (KM249137.1) and HSP60 sequences (KM249138.1), all the isolates had 100\% sequence identity. Based on the RPB2 sequence, five of the isolates had $100 \%$ sequence identity with each other (KM249120.1), while F738 (KM249121.1) differed by two nucleotides. Based on phylogenetic analysis with the G3PDH, HSP60, and RPB2 sequences, all six of these isolates were similar to B. cinerea strain GBC-1 (Fig. 2).

Based on the ITS-5.8S rDNA sequences, two of the Penicillium isolates (F727 and F728) had 100\% sequence identity (KM249068.1), while three other isolates of this genus (F730, F731, and F732) differed by one to nine nucleotides (KM249070.1, KM249071.1, and KM249072.1, respectively). Based on the LSU sequences, the Penicillium isolates F728, F730, and F732 had 100\% sequence identity (KM249090.1), while isolates F727 and F731 differed by 2 to 12 bases (KM249089.1 and KM249091.1, respectively). Based on the TUB and RPB2 sequences, Penicillium isolates F727, F728, F730, and F732 had $100 \%$ sequence identity (KM249108.1 and KM249117.1 for TUB and RPB2, respectively), while isolate F731 differed by 27 or more bases (KM249109.1 and KM249119.1, respectively). When evaluated using
BLASTn searches, the Penicillium isolates and one Talaromyces isolate (F729) had $\geq 97 \%$ sequence identity with multiple species or $\leq 96 \%$ sequence identity with all accessions in that genus. Thus, these isolates were compared with strains used to establish the recognized species based on concatenated sequences from the following DNA regions: ITS-5.8S, LSU, TUB, and RPB2. Four of the Penicillium isolates (F727, F728, F730, and F732) grouped together but separately from other Penicillium spp. (Fig. 3) and were most closely related to Penicillium freii strain CBS794 based on Jukes-Cantor (JC) distance matrix. Isolate F731 also grouped alone in the phylogram and was most closely related to $P$. viridicatum Westling strain CBS101034 based on the JC distance matrix. Isolate F729 grouped with T. rugulosus strain NRRL 1045 (Fig. 4) based on concatenated sequences from the ITS-5.8S rDNA and RPB2 regions.

Based on the ITS-5.8S rDNA, LSU, and ACT sequences, the five Phoma isolates F739 to F743 had 98 to $100 \%$ sequence identity (consensus sequences KM249075.1 to KM249078.1, KM249093.1 to KM249097.1, and KM249131.1 to KM249133.1 for these three DNA regions, respectively) with that of Phoma betae reference strain CBS523.66 (FJ426981.1, EU754179.1, and JF740118.1, respectively). For the RPB2 sequences, the strains had 98 to $99 \%$ sequence identity (KM249122.1 to KM249126.1 for F739 to F734, respectively) with P. betae reference strain CBS109410 (GU371774.1).

Sequences of the three Fusarium isolates F747, F748, and F749 were submitted to the FUSARIUM MLST database to facilitate identification based on sequence data from the ITS-5.8S rDNA (KM249081.1 to KM249083.1), TUB (KM249115.1 and KM249116.1),

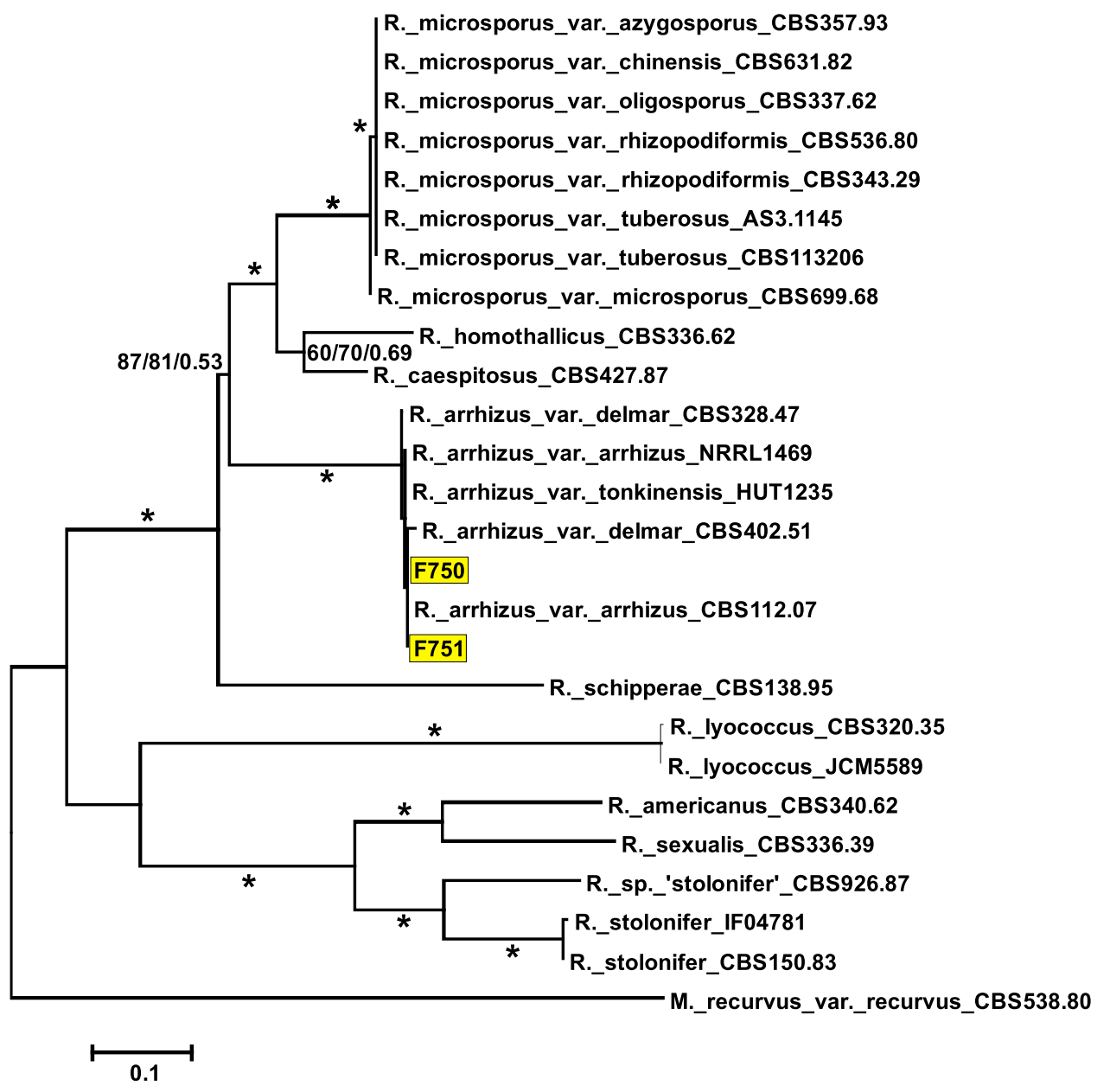

Fig. 6. Phylogenetic relationships among Rhizopus spp. and two fungal isolates ( $F 750$ and $F 751$, noted by the yellow boxes) collected from sugar beet roots in an Idaho commercial storage facility based on the sequences from the internal transcribed spacer-5.8S ribosomal DNA region. The length of the concatenated sequences was 913 nucleotides (nt), of which $272 \mathrm{nt}$ were conserved, $641 \mathrm{nt}$ were variable, and $486 \mathrm{nt}$ were parsimony informative. Numbers on nodes represent the statistical support for maximum likelihood (ML; 1,000 replicates, left number), maximum parsimony (MP; 1,000 bootstrap replicates, middle number), and Bayesian method (posterior probabilities, right number). Asterisks indicate support of $\geq 95 \%$ for ML and MP and $\geq 0.95$ for the Bayesian method. Rhizopus spp. sequences were obtained from GenBank and the names are followed by strain designations. The tree was rooted to Mucor recurvus var. recurvus strain CBS538.80 (GenBank accession number HM999964.1) 
LSU (KM249101.1 to KM249103.1), and translation elongation factor (KM249134.1 to KM249136.1) regions. All three isolates fell into a clade with the $F$. tricinctum species complex strains NRRL 34036 and NRRL 36147.

The two Mucor isolates F752 and F753 were compared with the DNA sequences of Mucor spp. from the ITS-5.8S rDNA and LSU regions (Fig. 5). Isolate F752 was placed between Mucor circinelloides f. circinelloides strain CBS108.16 and M. circinelloides $\mathrm{f}$. lusitanicus strain CBS111228 in the phylogram. Isolate F753 was closely related to M. hiemalis f. corticola strain CBS362.68.

Rhizopus isolates F750 and F751 were compared with sequence data for Rhizopus spp. from the ITS-5.8S rDNA region (Fig. 6). Both isolates were grouped with $R$. arrhizus var. arrhizus strain CBS112.07. Sarocladium isolates F745 and F746 had 99 to $100 \%$ sequence identity with the ITS-5.8S rDNA and LSU regions for the S. strictum (syn. Acremonium strictum) type strain CBS346.70 (AY138845.1 and HQ232141.1, respectively). Neonectria isolate F744 had 97 to $100 \%$ sequence identity with the ITS-5.8S (JF735313.1), LSU (HM042436.1), RPB2 (DQ789792.1), and TUB (HM054124.1) sequences of $N$. ramulariae type strain CBS151.29.

\section{Discussion}

Differences in root surface area with fungal growth, root weight, and sucrose loss were evident when sugar beet roots were held in storage up to 148 days after the roots had been harvested over a 5-week period from BNYVV-infested fields in Idaho at low or high incidences of rhizomania and treated with one of three fungicides (Mertect, Propulse, or Stadium). Nontreated roots harvested the first week had more fungal growth on the root surface compared with roots harvested in week 5 (11 to 51\% surface area with fungal growth for week 1 versus 1 to $5 \%$ for week 5), more root surface discoloration ( 10 to $12 \%$ versus $4 \%$ ), and greater sucrose loss ( 25 to 35 versus 18 to $19 \%$ ). Similar differences were evident regardless of the incidence of rhizomania in the fields from which the roots were harvested, because roots harvested at week 1 had more fungal growth on the root surface than roots harvested at week 5 (4 to $40 \%$ for week 1 versus 1 to $2 \%$ for week 5), more root surface discoloration (4 to $13 \%$ versus 1 to $2 \%$ ), and greater sucrose loss (20 to 39 versus 15 to $19 \%$ ). Thus, placing roots in storage later in October in Idaho should reduce storage problems (rot, sucrose reduction, and weight loss) compared with roots harvested in late September or early October.

Roots harvested from a field with a high incidence of rhizomania had more fungal growth on the root surface in 14 of 20 root evaluations and more sucrose loss in 8 of 10 evaluations. The application of either Propulse or Stadium reduced fungal growth on the root surface compared with the control roots by an average of 84 to $100 \%$ for roots collected from the field during the first 3 weeks (late September to early October) in both years. Both Propulse and Stadium treatments also reduced root surface discoloration compared with the control roots by an average of 75 to $100 \%$ for roots collected across the 5 weeks in both years, except for 2012 roots treated with Stadium in week 1, which did not differ from the control roots. Compared with the Mertect treatment, both Propulse and Stadium treatments reduced root surface discoloration by 50 to $100 \%$ and fungal growth 46 to $67 \%$ when significant differences (6 of 10 and 8 of 20 evaluations, respectively) were observed. Compared with Mertect-treated roots, both Propulse and Stadium treatments reduced sucrose loss by 16 to $39 \%$ in 6 of 10 times when differences in sucrose loss were observed. Propulse did not differ from Stadium in terms of reducing sucrose loss except for roots from 1 week of harvest (week 3 with 2013 roots). The roots treated with Mertect typically did not differ from the control roots in terms of fungal growth on the root surface (10 of 20 evaluations) and sucrose loss (6 of 10 evaluations).

Fungal-related sugar beet storage root rots have been investigated in the past, particularly in the 1970s. During the 1974-75 storage season in the Red River Valley of Minnesota and North Dakota, the total loss of sucrose in sugar beet storage was estimated at $>7,700$ tons (11). The three primary fungal pathogens involved were $P$. betae, Penicillium vulpinum (Cooke \& Massee) Seifert \& Samson (formerly
P. claviforme Bainier), and B. cinerea (teleomorph B. fuckeliana) (11). The prevalence of Phoma betae was slightly greater than that of Penicillium vulpinum and both were more prevalent than B. cinerea (11). In 1982 in the Red River Valley, Phoma betae and Penicillium vulpinum were found in $70 \%$ of sugar beet rot isolations, whereas Fusarium spp. were isolated from $31 \%$ of the samples and B. cinerea from only $2 \%(8)$. In other sugar beet production areas in the United States such as Colorado and Washington, species of Botrytis, Fusarium, Mucor, Rhizopus, and Penicillium have been reported as important in sugar beet storage rots $(31,32)$. Researchers from Russia and Europe have also acknowledged the importance of Botrytis, Fusarium, Phoma, and Penicillium spp. in sugar beet storage rots $(14,29,34)$. Isolations from Idaho sugar beet roots in storage in this study showed a similar mix of fungi, because $B$. cinerea, Penicillium spp., Phoma betae, and Fusarium spp. were among the most prevalent fungi isolated. However, the Athelia-like sp. (55) was the most prevalent fungus associated with aerial mycelium in both years of this study, even though this fungus had not been mentioned in sugar beet storage work prior to the first report from Idaho in 2009 (49). In that study by Strausbaugh et al. (49), this fungus was the most prevalent of the fungi detected in root storage. The Athelia-like fungus seems to be found commonly in association with BNYVV. BNYVV has only been documented in the United States since 1984 in California; since 1992 to 1994 in Colorado, Idaho, Minnesota, Nebraska, North Dakota, and Wyoming; and since 2002 in Oregon and Washington $(33,42,49,51)$. Previous literature reporting Penicillium spp. in association with sugar beet storage rots has primarily attributed such rots to Penicillium vulpinum (formerly $P$. claviforme) $(8,9,12,22,29,34)$. However, the Penicillium spp. isolated from Idaho sugar beet roots in this study did not include $P$. vulpinum based on phylogenetic analyses. Four of the Penicillium isolates (F727, F728, F730, and F732) were grouped separately from other recognized species. Based on the genetic distance calculated, these isolates were most closely related to P. freii strain CBS794.95. Penicillium isolate F731 was most closely related to $P$. hirsutum strain DAOM221131. Both P. freii and P. hirsutum are in Section Fasciculata (all species in this section are psychrotolerant) of the subgenus Penicillium, while P. vulpinum is in Section Penicillium of the subgenus Penicillium (25).

Another difference between the results of this study and previous reports from the Red River Valley of fungi associated with sugar beet root rot in storage was the frequency of detection of $B$. cinerea and Phoma betae. Observations from both the aerial mycelium and root lesion isolations in this study suggested that $B$. cinerea was a more prevalent component of the sugar beet storage rot complex in Idaho indoor storage facilities (19 to 43\%, depending on the isolation temperature and year in which the roots were sampled) than that described for the Red River Valley ( $2 \%$ of the rot tissues assayed) $(8,11)$. Although $P$. betae was present in $70 \%$ of the isolations from sugar beet roots in the Red River Valley (8), this pathogen was only detected in 11 to $24 \%$ of the Idaho root isolations.

$F$. tricinctum was isolated from roots sampled in Idaho in this study, while the Fusarium spp. detected in the Red River Valley study were not identified to species. Fusarium species documented from other United States and European sugar beet areas have included $F$. acuminatum Ellis. \& Everh., F. avenaceum (Fr.) Sacc., F. culmorum (Wm. G. Sm.) Sacc., F. cerealis (Cooke) Sacc., F. equiseti (Corda) Sacc., F. graminearum Schwabe, F. oxysporum Schltdl., F. redolens Wollen., F. solani (Mart.) Sacc., F. sporotrichioides Sherb., and F. subglutinans (Wollenw. \& Reinking) P. E. Nelson, Toussoun \& Marasas $(7,19)$. Fusarium, Rhizopus, and Mucor spp. have been associated with beet rot in storage in the United States but appeared to be minor components of the rot complex, unless the roots were stored at $\geq 23^{\circ} \mathrm{C}(31,46)$. Lower storage temperatures $\left(\leq 10^{\circ} \mathrm{C}\right)$ seem to favor the Athelia-like fungus and Botrytis, and Penicillium spp. (31,55). Because this Idaho study was conducted in a commercial indoor storage facility with a temperature set point (target temperature) of $1.1^{\circ} \mathrm{C}$, the mix of fungi found in other storage studies might differ in the past as a result of differences in storage temperatures among studies. Although a range of fungi were isolated 
internally from sugar beet root lesions in this study, not all of these fungi are well-established pathogens of sugar beet, including the Athelia-like sp., Cladosporium spp., F. tricinctum, Mucor sp., $N$. ramulariae, $R$. arrhizus, $S$. strictum, and T. rugulosus.

In previous studies, $B$. cinerea was found to cause more prevalent sugar beet root rot than Penicillium vulpinum when isolates of each were inoculated onto sugar beet alone; however, $P$. vulpinum was antagonistic to $B$. cinerea when isolates of the two species were coinoculated (8). In a previous study with isolates of the Athelia-like sp., the genus Penicillium was the most frequent fungus reisolated from internal root tissue even though Penicillium was not inoculated and the noninoculated control roots were not colonized by Penicillium spp., even though plugs were pulled to establish these treatments while in a nonsterile environment inside a commercial storage building (49). Penicillium-induced storage rot of sugar beet roots is known frequently to be associated with root wounds (22) but plugs pulled from the sugar beet roots for the noninoculated controls did not become contaminated (49). Thus, wounding plus the presence of the Athelia-like fungus may facilitate Penicillium spp. to colonize sugar beet roots.

Previous investigations have indicated that rhizomania caused by BNYVV can cause loss in sucrose during the storage of sugar beet roots $(17,49,51)$. This study confirmed the potential negative effect of BNYVV on roots in storage in terms of enhancing fungal growth, root rot, and sucrose loss when significant differences could be proven. As fungal growth on the sugar beet root surfaces increased, root rot was worse (except for roots sampled in week 3 in 2013) and sucrose loss was greater for roots sampled from the field with a high rhizomania incidence compared with roots from a field with low rhizomania incidence. Perhaps differences in fungal growth, root rot, and sucrose loss would have always been significant if the lowincidence field had no rhizomania and a less resistant cultivar had been used. However, most if not all commercial sugar beet fields in Idaho have some level of rhizomania (33) and commercial cultivars are required to have at least a similar level of resistance as B-5 $(47,48)$, the cultivar used in this study.

The storage building used in this sugar beet study reached the temperature set point of $1.1^{\circ} \mathrm{C} 22$ days sooner for the 2013 harvested roots than the 2012 harvested roots, which may have affected detection of fungal growth on roots from the 2013 season versus roots from the 2012 season. Harvesting the roots from mid-September to mid-October encompassed the first 4 weeks of a typical 6-week commercial harvest period for sugar beet crops in south-central Idaho (26). When the week 5 roots were placed into storage each year, the commercial indoor storage building was approximately $75 \%$ full and 5 to 7 days from being completely full. The roots were taken out of storage, rated in early February, and processed to generate brei samples for sucrose analysis soon after rating. This early-February processing identified considerable sucrose losses (35 and 25\% loss in week 1 controls in 2012 and 2013, respectively) but likely does not represent a worst-case scenario, because commercial roots were not emptied out of the storage building for another 5 to 6 weeks (26).

Fungicide applications have been investigated for the control of sugar beet storage rots $(1,8,31)$. The only fungicide currently approved in the U. S. for application to sugar beet roots going into storage to control rots is thiabendazole, sold as Mertect or TBZ (8). Mertect has been reported to reduce rot caused by Botrytis and Penicillium spp. but is not efficacious for controlling Phoma betae (8). The current label for Mertect 340F in the United States does not include sugar beet but does include applications for control of fungal contaminants in mushroom (i.e., Basidiomycete) production. Because the Athelia-like fungus is a Basidiomycete and was the most prevalent fungus detected on roots in this study, and $P$. betae was frequently present in the sugar beet roots, this may explain the poor performance of Mertect against fungal storage rot in the study. In contrast, both Propulse and Stadium provided excellent control; therefore, these fungicides should be considered for controlling sugar beet storage rots. Propulse ranked better than Stadium for reducing sucrose loss in 8 of 10 evaluations in the study. Propulse was recently labeled for use in the United States on sugar beet for powdery mildew control but is not labeled currently for use in storage. In addition to storing roots for sucrose production, sugar beet roots are placed in cold storage by seed companies and breeders to vernalize the roots for seed production the next year. The same storage fungi evaluated in the commercial sugar beet storage facility in this study could negatively affect roots held in storage for seed production. A preliminary evaluation of Propulse on roots stored for seed production at the United States Department of Agriculture-Agricultural Research Service Northwest Irrigation and Soils Research Laboratory in Kimberly, ID (data not shown) suggests the product should work well to protect roots used for seed production. Thus, once these fungicides are labeled for use on stored sugar beet roots, they should be used in commercial sugar beet storage and on roots being vernalized for seed production.

\section{Acknowledgments}

These data support the objectives of the United States Department of Agriculture CRIS project 5368-21220-003-00D. We thank the Amalgamated Sugar Co. LLC, Amalgamated Research, LLC, Beet Sugar Development Foundation, and Snake River sugar beet growers for supporting our research; and J. Reed, D. Kenney, and T. Brown for their technical support.

\section{Literature Cited}

1. Akeson, W. R., Yun, Y. M., and Sullivan, E. F. 1979. Effect of chemicals on sucrose loss in sugarbeets during storage. J. Am. Soc. Sugar Beet Technol. 20: 255-268.

2. Altschul, S. F., Madden, T. L., Schäffer, A. A., Zhang, J., Zhang, Z., Miller, W., and Lipman, D. J. 1997. Gapped BLAST and PSI-BLAST: A new generation of protein database search programs. Nucleic Acids Res. 25: 3389-3402.

3. Aveskamp, M. M., de Gruyter, J., Woudenberg, J. H. C., Verkley, G. J. M., and Crous, P. W. 2010. Highlights of the Didymellaceae: A polyphasic approach to characterize Phoma and related pleosporalean genera. Stud. Mycol. 65:1-60.

4. Aveskamp, M. M., Verkley, G. J. M., de Gruyter, J., Murace, M. A., Perello, A., Wollenberg, J. H. C., Groenewald, J. Z., and Crous, P. W. 2009. DNA phylogeny reveals polyphyly of Phoma section Peyronellaea and multiple taxonomic novelties. Mycologia 101:363-382.

5. Bensch, K., Braun, U., Groenewald, J. Z., and Crous, P. W. 2012. The genus Cladosporium. Stud. Mycol. 72:1-401.

6. Bernhardson, D. 2009. Sugarbeet storage techniques developed. Int. Sugar J. 111:628-631.

7. Bosch, U., and Mirocha, C. J. 1992. Toxin production by Fusarium species from sugar beets and natural occurrence of zearalenone in beets and beet fibers. Appl. Environ. Microbiol. 58:3233-3239.

8. Bugbee, W. M. 1982. Storage rot of sugar beet. Plant Dis. 66:871-873.

9. Bugbee, W. M. 1993. Storage. Pages 551-570 in: The Sugar Beet Crop: Science into Practice. D. A. Cooke and R. K. Scott, eds. Chapman and Hall, London.

10. Bugbee, W. M., and Campbell, L. G. 1990. Combined resistance in sugar beet to Rhizoctonia solani, Phoma betae, and Botrytis cinerea. Plant Dis. 74 353-355.

11. Bugbee, W. M., and Cole, D. F. 1976. Sugarbeet storage rot in the Red River Valley 1974-75. J. Am. Soc. Sugar Beet Technol. 19:19-24.

12. Bugbee, W. M., and Cole, D. F. 1979. Comparison of thiabendazole and genetic resistance for control of sugar beet storage rot. Phytopathology 69: 1230-1232.

13. Campbell, L. G., and Bugbee, W. M. 1988. Selection for improved sugarbeet storability. Crop Sci. 28:33-36.

14. Campbell, L. G., and Bugbee, W. M. 1993. Pre-breeding for root-rot resistance. J. Sugar Beet Res. 30:241-251.

15. Campbell, L. G., Fugate, K. K., and Niehaus, W. S. 2011. Fusarium yellows affects postharvest respiration rate, sucrose concentration, and invert sugar in sugarbeet. J. Sugar Beet Res. 48:17-39.

16. Campbell, L. G., and Klotz, K. L. 2006. Postharvest storage losses associated with Aphanomyces root rot in sugarbeet. J. Sugar Beet Res. 43:113-127.

17. Campbell, L. G., Klotz, K. L., and Smith, L. J. 2008. Postharvest storage losses associated with rhizomania in sugar beet. Plant Dis. 92:575-580.

18. Chaverri, P., Salgado, C., Hirooka, Y., Rossman, A. Y., and Samuels, G. J. 2011. Delimitation of Neonectria and Cylindrocarpon (Nectriaceae, Hypocreales, Ascomycota) and related genera with Cylindrocarpon-like anamorphs. Stud. Mycol. 68:57-78.

19. Christ, D. S., Märländer, B., and Varrelmann, M. 2011. Characterization and mycotoxigenic potential of Fusarium species in freshly harvested and stored sugar beet in Europe. Phytopathology 101:1330-1337.

20. de Gruyter, J., Woudenberg, J. H. C., Aveskamp, M. M., Verkley, G. J. M. Groenewald, J. Z., and Crous, P. W. 2013. Redisposition of Phoma-like anamorphs in Pleosporales. Stud. Mycol. 75:1-36.

21. Fournier, E., Giraud, T., Albertini, C., and Brygoo, Y. 2005. Partition of the Botrytis cinerea complex in France using multiple gene genealogies. Mycologia 97:1251-1267. 
22. Fugate, K., and Campbell, L. 2009. Postharvest deterioration of sugar beet. Pages 92-94 in: Compendium of Beet Diseases and Pests, 2nd ed., R. M. Harveson, L. E. Hanson, and G. Hein, eds. American Phytopathological Society, St. Paul, MN.

23. Fugate, K. K., Ferrareze, J. P., Bolton, M. D., Deckard, E. L., and Campbell, L. G. 2012. Postharvest jasmonic acid treatment of sugarbeet roots reduces rot due to Botrytis cinerea, Penicillium claviforme, and Phoma betae. Postharvest Biol. Technol. 65:1-4

24. Hall, T. 1999. BioEdit: A user-friendly biological science sequence alignment editor and analysis program for Windows 95/98/NT. Nucleic Acids Symp. Ser. 41:95-98.

25. Houbraken, J., and Samson, R. A. 2011. Phylogeny of Penicillium and the segregation of Trichocomaceae into three families. Stud. Mycol. 70:1-51.

26. Huff, J. 2013. The hidden cost of beet storage. Sugarbeet (2013 Harvest Issue): 3-4. Amalgamated Sugar Company, LLC, Boise, ID.

27. Klotz, K. L., and Campbell, L. G. 2009. Effects of Aphanomyces root rot on carbohydrate impurities and sucrose extractability in postharvest sugar beet. Plant Dis. 93:94-99.

28. Larkin, M. A., Blackshields, G., Brown, N. P., Chenna, R., McGettigan, P. A., McWilliam, H., Valentin, F., Wallace, I. M., Wilm, A., Lopez, R., Thompson, J. D., Gibson, T. J., and Higgins, D. G. 2007. Clustal W and Clustal X version 2.0. Bioinformatics 23:2947-2948.

29. Liebe, S., and Varrelmann, M. 2014. Impact of root rot pathogens on storage of sugar beets and control measures. Sugar Ind. 139:443-452.

30. Liu, Y. J., Whelen, S., and Hall, B. D. 1999. Phylogenetic relationships among ascomycetes: Evidence from an RNA polymerase II subunit. Mol. Biol. Evol. 16:1799-1808.

31. Miles, W. G., Shaker, F. M., Nielson, A. K., and Ames, R. R. 1977. A laboratory study on the ability of fungicides to control beet rotting fungi. J. Am. Soc. Sugar Beet Technol. 19:288-293.

32. Mumford, D. L., and Wyse, R. E. 1976. Effect of fungus infection on respiration and reducing sugar accumulation of sugarbeet roots and use of fungicides to reduce infection. J. Am. Soc. Sugar Beet Technol. 19:157-162.

33. Neher, O. T., and Gallian, J. J. 2014. Rhizomania on sugar beet-Importance, identification, and control. Pac. NW Ext. Publ. PNW 657. University of Idaho, Moscow.

34. Nihlgård, M., Levall, M., Jonsson, R., Lennefors, B.-L., Larson, R., and Steinrucken, G. 2009. Storage diseases-Assessment and implications for breeding. (Abstr.) J. Sugar Beet Res. 46:91.

35. O’Donnell, K., Humber, R. A., Geiser, D. M., Kang, S., Park, B., Robert, V. A. R. G., Crous, P. W., Johnston, P. R., Aoki, T., Rooney, A. P., and Rehner, S. A. 2012. Phylogenetic diversity of insecticolous fusaria inferred from multilocus DNA sequence data and their molecular identification via FUSARIUM-ID and Fusarium MLST. Mycologia 104:427-445.

36. O'Donnell, K., Sutton, D. A., Fothergill, A., McCarthy, D., Rinaldi, M. G., Brandt, M. E., Zhang, N., and Geiser, D. 2008. Molecular phylogenetic diversity, multilocus haplotype nomenclature, and in vitro antifungal resistance within the Fusarium solani species complex. J. Clin. Microbiol. 46:2477-2490.

37. Peterson, C. L., Hall, M. C., and Traveller, D. J. 1984. Sugarbeet storage experiments. Am. Soc. Agric. Eng. Pap. No. 84-4040. ASAE, Knoxville, TN.

38. Peterson, C. L., Traveller, D. J., and Hall, M. C. 1980. Loss of sucrose during controlled and conventional storage. J. Am. Soc. Sugar Beet Technol. 20: 517-530.

39. Peterson, S. W., and Jurjević, Ž. 2013. Talaromyces columbinus sp. nov., and genealogical concordance analysis in Talaromyces Clade 2a. PLoS One 8: e78084.

40. Reeb, V., Lutzoni, F., and Roux, C. 2004. Contribution of RPB2 to multilocus phylogenetic studies of the euascomycetes (Pezzomycotina, Fungi) with special emphasis on the lichen-forming Acarosporaceae and evolution of polyspory. Mol. Phylogenet. Evol. 32:1036-1060.

41. Ronquist, F., and Huelsenbeck, J. P. 2003. MrBayes 3: Bayesian phylogenetic inference under mixed models. Bioinformatics 19:1572-1574.

42. Rush, C. M., Liu, H.-Y., Lewellen, R. T., and Acosta-Leal, R. 2006. The continuing saga of rhizomania of sugar beets in the United States. Plant Dis. 90:4-15.
43. Samson, R. A., Yilmaz, N., Houbraken, J., Spierenburg, H., Seifert, K. A. Peterson, S. W., Varga, J., and Frisvad, J. C. 2011. Phylogeny and nomenclature of the genus Talaromyces and taxa accommodated in Penicillium subgenus Biverticillium. Stud. Mycol. 70:159-183.

44. Smith, G. A., and Ruppel, E. G. 1971. Cercospora leaf spot as a predisposing factor in storage rot of sugar beet roots. Phytopathology 61:1485-1487.

45. Staats, M., van Baarlen, P., and van Kan, J. A. L. 2005. Molecular phylogeny of the plant pathogenic genus Botrytis and the evolution of host specificity. Mol. Biol. Evol. 22:333-346.

46. Strausbaugh, C. A., Eujayl, I. A., and Foote, P. 2013. Selection for resistance to the Rhizoctonia-bacterial root rot complex in sugar beet. Plant Dis. 97 93-100.

47. Strausbaugh, C. A., Eujayl, I. A., and Rearick, E. 2013. Commercial sugar beet cultivars evaluated for rhizomania resistance and storability in Idaho, 2012 Plant Dis. Manage. Rep. 7:FC116.

48. Strausbaugh, C. A., Eujayl, I. A., Rearick, E., and Foote, P. 2013. Commercia sugar beet cultivars evaluated for resistance to rhizomania and storability in Idaho, 2011. Plant Dis. Manage. Rep. 7:FC077

49. Strausbaugh, C. A., Eujayl, I. A., Rearick, E., Foote, P., and Elison, D. 2009. Sugar beet cultivar evaluation for storability and rhizomania resistance. Plant Dis. 93:632-638.

50. Strausbaugh, C. A., Rearick, E., and Camp, S. 2008. Influence of curly top and Poncho Beta on storability of sugarbeet. J. Sugar Beet Res. 45:31-47.

51. Strausbaugh, C. A., Rearick, E., Camp, S., Gallian, J. J., and Dyer, A. T. 2008 Influence of Beet necrotic yellow vein virus on sugar beet storability. Plant Dis. 92:581-587.

52. Strausbaugh, C. A., Rearick, E., Eujayl, I. A., and Foote, P. 2011. Influence of Rhizoctonia-bacterial root rot complex on storability of sugarbeet. J. Sugar Beet Res. 48:155-180.

53. Summerbell, R. C., Gueidan, C., Schroers, H.-J., de Hoog, G. S., Starink, M., Arocha Rosete, Y., Guarro, J., and Scott, J. A. 2011. Acremonium phylogenetic overview and revision of Gliomastix, Sarocladium, and Trichothecium. Stud. Mycol. 68:139-162.

54. Tamura, K., Peterson, D., Peterson, N., Stecher, G., Nei, M., and Kumar, S 2011. MEGA5: Molecular evolutionary genetics analysis using maximum likelihood, evolutionary distance, and maximum parsimony methods. Mol. Biol. Evol. 28:2731-2739.

55. Toda, T., Strausbaugh, C. A., Rodriquez-Carres, M., and Cubeta, M. A. 2012 Characterization of a Basidiomycete fungus from stored sugar beet roots. Mycologia 104:70-78.

56. Van Driessche, R. 2012. Michigan sugar company "Ten years of progress". Sugar Prod. Mag. (March 2012):21. Harris Publishing Inc., Idaho Falls, ID.

57. Van Eerd, L. L., Congreves, K. A., and Zandstra, J. W. 2012. Sugar beet (Beto vulgaris L.) storage quality in large outdoor piles is impacted by pile management but not by nitrogen fertilizer or cultivar. Can. J. Plant Sci. 92:129-139.

58. Vilgalys, R., and Hester, M. 1990. Rapid genetic identification and mapping of enzymatically amplified ribosomal DNA from several Cryptococcus species. J. Bacteriol. 172:4238-4246.

59. Walther, G., Pawłowska, J., Alastruey-Izquierdo, A., Wrzosek, M., Rodriguez-Tudela, J. L., Dolatabadi, S., Chakrabarti, A., and de Hoog, G. S. 2013. DNA barcoding in Mucorales: An inventory of biodiversity. Persoonia 30:11-47.

60. White, T. J., Bruns, T., Lee, S., and Taylor, J. 1990. Amplification and direct sequencing of fungal ribosomal RNA genes for phylogenetics. Pages 315-322 in: PCR Protocols: A Guide to Methods and Applications. M. A. Innis, D. H Gelfand, J. J. Sninsky, and T. J. White, eds. Academic Press, San Diego, CA

61. Wu, M. T., Singh, B., Theurer, J. C., Olson, L. E., and Salunkhe, D. K. 1970. Control of sucrose loss in sugarbeet during storage by chemicals and modified atmosphere and certain associated physiological changes. J. Am. Soc. Sugar Beet Technol. 16:117-127.

62. Wyse, R. 1978. Effect of low and fluctuating temperatures on storage life of sugarbeets. J. Am. Soc. Sugar Beet Technol. 20:33-42.

63. Zhou, Y. J., Wang, X. D., Yang, L., Jiang, D. H., Li, G. Q., Hsiang, T., and Zhuang, W. Y. 2014. Morphological and phylogenetic identification of Botrytis sinoviticola, a novel cryptic species causing gray mold disease of table grapes (Vitis vinifera) in China. Mycologia 106:43-56. 